\title{
Who Are the First Users of a Newly-Emerging International Currency? A Demand-Side Study of Chinese Renminbi Internationalization
}

Hyoung-kyu Chey*, Geun-Young Kim**, and Dong Hyun Lee***

The views expressed herein are those of the authors and do not necessarily reflect the official views of the Bank of Korea. When reporting or citing this paper, the authors' names should always be explicitly stated.

* Corresponding Author, Associate Professor of International Political Economy, National Graduate Institute for Policy Studies (GRIPS), E-mail: hyoung-kyu@grips.ac.jp.

** Head, Research Department, The Bank of Korea, Tel: +82-2-759-5280, E-mail: kgy3104@bok.or.kr. *** Senior Economist, Economic Research Institute, The Bank of Korea, Tel: +82-2-759-5441, E-mail: dukelee@bok.or.kr.

We wish to thank Kwang Myoung Hwang, Michael Marking, an anonymous reviewer and seminar participants at the Bank of Korea for helpful comments, as well as Stefan Angrick and Yooran Shin for their excellent research assistance. 


\section{Contents}

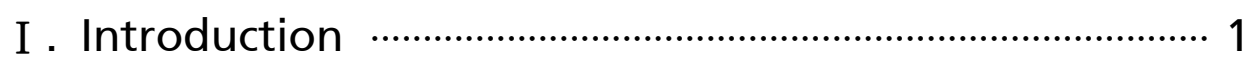

II. Framing of the Research Question ……………………. 5

III. Accounts of First Moves to the RMB …………….... 13

IV. Data and Methodology ……………………………........ 20

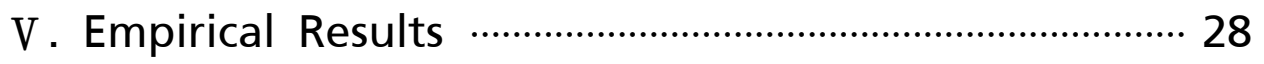

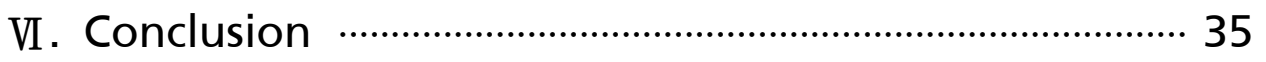

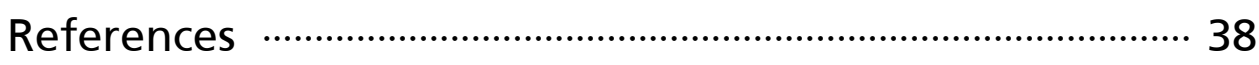

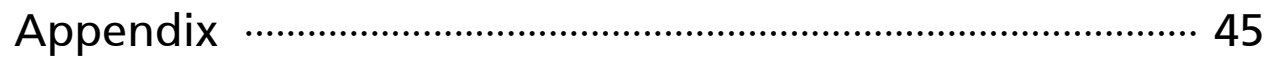




\section{Who Are the First Users of a Newly-Emerging International Currency? A Demand-Side Study of Chinese Renminbi Internationalization}

Who are the first users of a newly-internationalizing currency? This issue, crucial to understanding the dynamics of the emergence of a new international monetary order, remains long underexplored in the existing literature, which tends to adopt a supply-side approach analyzing mainly the international currency issuers. Our study addresses this important question, with a focus on the case of the Chinese renminbi, by employing a demand-side approach examining the international currency users through generalized ordered logistic regression analysis. Our primary argument is that a state hosting a major global financial center - a condition largely independent of influence from countries issuing international currencies - is likely to be more interested in enhancing its use of the renminbi, implying thereby that global financial institutions and the related inter-state rivalries among international currency users may play crucial roles in the shaping of a new international monetary order. We in addition find significant impacts on a state's interest in renminbi use resulting from its institutional economic cooperation with China through a preferential trade agreement or a bilateral investment treaty, but that a country's mere trade and investment integration with China does not meaningfully affect its government's support for renminbi use.

Keywords: Currency internationalization, International currency, Renminbi internationalization, Yuan internationalization

JEL Classification: F33, F50 


\section{Introduction}

On November 30, 2015 the International Monetary Fund (IMF) decided, effective October 2016, to include the Chinese renminbi (RMB) in the elite currency basket of the Special Drawing Right (SDR) - an international reserve asset issued by the IMF-along with the US dollar (hereafter the dollar), the euro, the Japanese yen and the British pound. This historic decision by the IMF reflects the growing internationalization of the RMB in recent years. That currency's international standing had been almost null until the late 2000s, despite the rapid growth of the Chinese economy. The Chinese authorities began to enthusiastically promote RMB internationalization (hereafter RMBI) from the time of the 2008 global financial crisis, however, by adopting a variety of deliberate policies to this end (see Chey and Li, 2016; Yu, 2014). Owing largely to these government efforts, RMBI has since shown dramatic acceleration in a short period of time. The RMB's rank as an international payments currency, for example, jumped from 35th in the world in October 2010 to fifth in October 2015. The currency became the sixth most popular currency for denomination of international debt securities in the first half of 2015, after having ranked 21st just five years earlier. The RMB also achieved the status of the seventh most used reserve currency in 2014 (IMF, 2015).

This remarkable progress in RMBI, along with mounting skepticism about the dollar since the crisis, has generated a new wave in the study of currency internationalization, attracting a large number of political economists in addition to the economists who have traditionally dominated analysis of the subject. A majority of this new research places its analytic focus on the issue of whether the dollar will maintain its status as the dominant international currency, or if the RMB will instead replace it or substantially challenge its standing. ${ }^{1)}$

1) See, for example, Bowles and Wang (2008), Chey (2012, 2013a, 2015), Cohen (2012b, 2015), Cohen and Benney (2014), Eichengreen (2011b, 2013), Eichengreen and Kawai (2014), Eichengreen and Lombardi (2015), Helleiner (2008), Helleiner and Kirshner (2009, 2014), Helleiner and Malkin (2012), Kirshner (2008, 2009), Lee (2014), Liao and McDowell (2015, 2016), Ly (2012), Norrlof (2014), Otero-Iglesias and Steinberg (2012, 2013), Stokes (2014), Subramanian (2011) and Subramanian and Kessler (2012). There 
Despite the recent abundance of research on currency internationalization, however, most studies are largely silent on the key issue related to RMBI of who the first foreign users of the RMB as an international currency have been.2) Our study addresses this salient question. The internationalization of the RMB, and of any other currency as well, can be expected to proceed unevenly across countries in the world. Not all countries have begun to increase their uses of the RMB at the same times and at the same speeds. Certain of them have shown stronger interest than others in using the RMB. At the beginning stages of a currency's internationalization, the convenience in using it is unlikely to be high. Its overall economic attractiveness tends to trail that of the incumbent key international currency, which enjoys well-established transaction networks (Chey, 2015). It is thus in general costly to become a first user of a newly-internationalizing currency. Nonetheless, certain foreign actors do begin to use a newly-internationalizing currency earlier than others who take 'wait-and-see' approaches (Liao and McDowell, 2016). And the internationalization of the currency is thus initiated by these particular first users of it.

The issue of who are the first users of a newly-internationalizing currency is a crucial one for the study of currency internationalization in general, going beyond the specific case of the RMB. It addresses the dynamics of the emergence of a new international monetary order, a subject still largely untouched in the literature. The existing studies of currency internationalization, including those of RMBI, do examine factors that affect the internationalization of a currency, presenting lists of its economic and political determinants. Most however discuss general conditions for currency internationalization, without identifying any specific factors that motivate the first users of a newly-emerging international currency in particular. As a result, the salient question of by whom among its

are also some studies that focus on the rivalry between the euro and the dollar. See, for example, Cohen (2009), Germain and Schwartz (2014) and McNamara (2008). Since the outbreak of the European debt crisis in the early 2010s, the euro has however lost a great deal of its attractiveness, and the focus of discussion on its future has shifted from the feasibility of its replacing the dollar as the leading international currency to that of its own survival.

2) A notable exception is recent research by Liao and McDowell $(2015,2016)$, which will be discussed in detail in the following section. 
enormous number of potential users the rise of a new international currency is initiated remains largely underexplored.

The analytic focus of this research on the users of international currencies leads it to employ a demand-side analysis, in contrast to the majority of currency internationalization studies that tend to adopt supply-side approaches concentrating on the economic and/or political conditions of the states issuing international currencies. A good number of studies actually do recognize the need to consider the demand side of currency internationalization for more complete understanding, ${ }^{3)}$ and a few do examine the usages of international currencies in some countries.4) Most of these tend to provide single case studies, however, with the result that generalization from their findings is not easy. They moreover pay little explicit attention to the issue of who first uses a new international currency. The present study, in contrast, examines this issue directly by conducting a large- $\mathrm{N}$ study, mainly through generalized ordered logistic regression analysis.

Our study is also distinctive in its examination of the level of RMB use in a country. It focuses mainly on individual governments' policies regarding RMB use in their jurisdictions, by measuring the extents of establishment of infrastructures supporting RMB use rather than analyzing actual use of the RMB in their markets. This choice has been made due in part to the practical obstacle of limitations in collecting cross-country data on RMB use in these markets. It may be justified from a theoretical perspective as well, however. As mentioned above, the inherent economic attractiveness of a newlyinternationalizing currency tends to be limited. And in this situation, use of the RMB in a country is likely to be influenced largely by its government's support through the creation of infrastructures favorable to it (Chey, 2015).

In explaining who the first users of the RMB are, we place our foremost analytic focus on the impacts of global financial centers. Although some recent research does look at the countries using international currencies, it tends to

3) See, for example, Cohen (1998), Helleiner (2008) and Helleiner and Kirshner (2009).

4) See, for example, Chey (2015), Johnson (2008), Katada (2008) and Otero-Iglesias and Steinberg (2012, 2013). 
stress mainly their relations with the countries issuing competing currencies. ${ }^{5)}$ We in contrast draw special attention to one condition in a country that is largely independent of its relationships with the international currency issuers, as a key explanatory variable accounting for the level of its government's support for RMB use. More specifically, we argue that, in a country that hosts a major global financial center, its government is likely to provide strong support for RMB use, and we indicate as the rationale behind this argument global financial institutions' profit-seeking behaviors and the inter-state rivalries that they give rise to. This argument is strongly supported by our empirical analysis.

We also analyze the impacts of a user country's economic and political relations with the countries issuing competing international currencies-focusing on China and the United States, the issuer of the incumbent key international currency-based largely on the literature. We find, in sharp contrast to the predictions of many existing studies, that on the whole a country's mere market integration through trade and investment with either of these two international currency issuers does not have substantial impacts on its government policies related to RMB use. Our analysis shows, however, that a country's government policy regarding the RMB is positively affected by its institutional economic cooperation with China through signing of a preferential trade agreement (PTA) and/or a bilateral investment treaty (BIT). A country's security ties with the United States meanwhile appear to adversely influence its government policy related to RMB use.

The remainder of this paper is organized as follows. In the subsequent section we review the literature, illuminating the need for analysis of the first users of a newly-internationalizing currency, and also explain how we will identify such first users. We thereafter discuss the major factors that may motivate the first users of a newly-internationalizing currency, presenting our core arguments. We next explicate the details of our empirical study and report its findings, before then delivering our conclusions in the final section.

5) See, for example, Liao and McDowell (2015, 2016). 


\section{Framing of the Research Question}

This section frames the key question of the present study, by calling attention to the need for analysis of the first users of a newly-internationalizing currency in order to better understand the dynamics of such a currency's emergence internationally.

\section{Need for analysis of first users}

The literature on currency internationalization has long studied its determinants, ${ }^{6}$ ) since as far back as the debate in the 1960 s over the future of the dollar as the key international currency (and of the British pound as well).7) Most economics-based studies indicate as the main determinants of currency internationalization a set of economic conditions, ${ }^{8)}$ including the shares of the issuing country in global output and trade, its degree of financial market development and its price level. These conditions affect the two fundamental economic requirements for internationalization of a currency-the confidence in its value and the convenience of its use (Chey, 2012, 2014).

Political economy studies of this issue meanwhile draw attention to the related political conditions. Some of this research deals mainly with domestic factors within the issuing countries. Broz (1997), Chey and Li (2016), Helleiner and Malkin (2012) and Katada (2008), for example, emphasize the influence on currency internationalization of the preferences of domestic actors toward it. Eichengreen (2013), Eichengreen and Kawai (2014), Germain and Schwartz

6) Another major research subject related to currency internationalization is its consequences. The consequences of the internationalization of a currency have been analyzed usually from the perspective of the issuing country rather than that of the countries using it. For analysis of the major benefits and costs of issuing an international currency, see Chey $(2012,2014)$ and Cohen $(2015)$. The consequences and the determinants of currency internationalization are in fact intertwined, since the consequences of a currency's internationalization determine who will support or oppose it.

7) See, for example, Cohen (1971), Despres, Kindleberger and Salant (1965), Kindleberger (1967), Salant (1964), Strange (1971), Swoboda (1968) and Triffin (1968).

8) See, for example, Chinn and Frankel (2007), Krugman (1984), Lee (2014), Lim (2006), Subramanian (2011), Tavlas (1991) and Tavlas and Ozeki (1992). 
(2014), McNamara (2008), Ly (2012) and Walter (2006) stress the impacts of domestic policies and institutions on currency internationalization. There are also political economy studies that consider the international factors affecting the issuing countries. Chey (2013a), Momani (2008), Pittaluga and Seghezza (2012) and Posen (2008), for instance, point to the international power of an issuing country, including through provision of foreign security assistance, as a key factor affecting the internationalization of its currency.

Although it will not likely be perfect, a list of the determinants of currency internationalization can be drawn from these studies for use in analyzing the feasibility of a currency's internationalization. Chinn and Frankel (2007) for example, focusing on a set of economic determinants, projected that the euro could replace the dollar as the leading reserve currency by the early 2020 s. Relying on Chinn and Frankel's (2007) method, studies such as Lee (2014) and Subramanian (2011) subsequently forecasted future trajectories of the RMB as an international currency.

Most of the determinants of currency internationalization presented in the literature are however factors related mainly to the countries issuing the currencies, rather than those using them. In other words, most existing studies tend to provide supply-side analyses focusing on the issuers. And as a result they have limits in enabling analysis of the matter of who the first users of a newly-internationalizing currency are, and the question of by whom the rise of a new international currency is driven thus remains quite underexplored.

The salience of understanding the first users of a newly-internationalizing currency cannot be overstated, as it is crucial for comprehending the dynamics of a new international currency's emergence. As mentioned earlier, one of the fundamental economic requirements for a currency's internationalization is convenience in its use (Chey, 2012, 2014). Yet, in the early stage of its internationalization, the very fact of its usage being at this time limited means that it will be much less convenient to use than the incumbent major international currencies, which hold already well-established transactional networks. In fact, the underdevelopment of and limited access to the Chinese 
financial markets substantially reduce motives for RMB use by limiting RMB investment opportunities (Chey, 2015). The transaction costs of using the currency also remain far higher than those of dollar use, as shown for instance by South Korean firms having in September 2015 paid exchange rate commissions on RMB letters of credit that were three percentage points higher than those for dollar ones (Chey, 2015). In addition, even when firms do decide to begin using the RMB, most will have to continue using the dollar as well, which means an increased number of currency exchange rate risks to deal with (Chey, 2015).

As a matter of fact, although the RMB's status as an international currency has advanced dramatically over the past few years, the absolute level of its use remains quite marginal. Despite its rank as the world's seventh reserve currency, the RMB has a share in total world reserves of just 1.1 percent (IMF, 2015). Although the currency is the fifth most used currency for global payments, it still accounts for less than 2 percent. And despite its rank as the sixth leading currency in terms of international debt securities denomination, the RMB's share is only about 1 percent of the world total here as well. There are numerous obstacles hindering use of the RMB, and it is still far from being what Susan Strange (1971) termed a 'top currency'-one most favored by the world market due to its economic superiority.

In general, the inherent economic attractiveness of a newly-emerging international currency is very likely to be much lower than those of the incumbent leading international currencies. Due to such significant obstacles to the use of a newly-emerging international currency, a majority of foreign actors tend to adopt wait-and-see approaches in the early stage of its internationalization. Certain actors do however begin to use that currency earlier than others, thus helping to drive and deepen its internationalization. The analysis of these first users of a newly-internationalizing currency is accordingly essential to understanding the process of emergence of a new international monetary regime. 


\section{A demand-side approach}

The analytic focus of this study, on the users of international currencies, leads it logically to a demand-side analysis, in contrast to the majority of existing studies that employ supply-side approaches addressing mainly the international currency issuers. There are some demand-side studies in the literature, but many have notable limitations. For example, while a good number of economics studies analyze countries' choices of currencies for trade,9) foreign exchange reserves ${ }^{10)}$ and anchors for exchange rate pegging,11) they tend to select and examine usually only one of the six money functions of an international currency, and overlook the others. ${ }^{12)}$ Meanwhile, a few political economy studies do present in-depth examinations of the uses of certain international currencies in some countries. Most of them conduct single case studies, however, which limits the generalizability of their findings. ${ }^{13)}$ In addition, despite their examinations of international currency users, few of these studies pay much attention to the key question of the present research-who it is that first uses a newly-internationalizing currency.

Notable exceptions from these limitations are two recent papers by Liao and McDowell $(2015$, 2016) that analyze RMBI. Both papers place their analytic focuses on the users of the RMB, and adopt large-N studies by conducting statistical analyses. The earlier paper (Liao and McDowell, 2015) examines which countries have signed bilateral currency swaps with China. It argues that a country with high bilateral trade flows or a PTA or BIT with China is more likely to establish a bilateral currency swap with that country. The latter paper

\footnotetext{
9) See, for example, Goldberg and Tille (2005).

10) See, for example, Dooley et al. (1989).

11) See, for example, Dooley et al. (2003), Frankel and Wei (1994), Fratzscher and Mehl (2011), Ito (2010), McKinnon (2009), Subramanian and Kessler (2012) and Kawai and Pontines (2014).

12) An international currency plays the three roles of money - as a medium of exchange, a unit of account, and a store of value - at both the public and the private levels, and accordingly performs six functions in total (Cohen, 1971, 2015).

13) See, for example, Chey (2015), Johnson (2008) and Otero-Iglesias and Steinberg (2012, 2013). Although a good number of political economy studies, including Cohen (1998) and Helleiner (2008), do recognize the need for demand-side analysis, the number of those that actually offer comprehensive consideration of the subject is limited.
} 
(Liao and McDowell, 2016) addresses the question of who have been the 'early-adopters' of the RMB as a new reserve currency, by examining the factors that have led central banks to hold RMB-denominated reserves. In contrast to the earlier paper, this second one stresses the impact of geopolitics on reserve currency choice, arguing in particular that as a state's preferences regarding the international order shift from favoring the US model to the Chinese one, its use of the RMB as a reserve currency tends to increase. ${ }^{14)}$

Our study extends Liao and McDowell's (2015, 2016) research. Our key research question is similar to theirs, especially that in their second paper, and we also adopt a demand-side approach employing a large- $\mathrm{N}$ analysis. Our study differs substantially from their research in at least two significant respects, however, and thus complements it. First, in examining the level of RMB use in a country, we focus on the degree of establishment of infrastructures favorable to RMB use, by comprehensively considering diverse infrastructural settings. Second, in accounting for differences in the degrees of RMB infrastructures across countries, we draw attention to user countries' statuses as global financial centers, a condition that is largely independent of influence from the international currency issuers, although we do also analyze their relationships with these issuers. We move on now to explain these issues in detail.

\section{Identification of first RMB users}

We identify the first users of the RMB as an international currency by analyzing the government policies toward RMB use in different countries, and more specifically by examining the levels of establishment of the key infrastructures supporting RMB use rather than the degrees of actual RMB use in their markets. Our focus on government policies is due in part to the practical difficulty of examining RMB usage in various markets, since the

14) Liao and McDowell (2016) do not however explain why central banks, whose primary concerns are monetary stability and financial stability, put more weight on geopolitical than economic concerns in their reserve currency choices, even though many advanced country central banks tend to enjoy decent levels of independence. 
necessary cross-country data are largely unavailable. Yet, this choice may be supported from a theoretical viewpoint as well. As discussed earlier, despite the impressive recent development of RMBI there are still considerable obstacles to use of the RMB remaining, and the absolute level of RMB use in the markets is indeed still extremely low. Given this marginal level of actual RMB use by market actors, the significance of differences in RMB use across countries may be questionable. Moreover, market actors' motivations for use of the RMB are likely to be substantially influenced by their governments' support for it through the creation of necessary infrastructures that reduce its costs. Where a government has built effective infrastructures favorable to RMB use, market actors' use of the currency is likely to eventually increase. In other words, the level of infrastructure available for RMB use may be a good leading indicator of actual RMB use in the markets. And in fact a recent study by Chey (2015), of RMB use in South Korea (hereafter Korea), shows that Korean financial institutions' interest in the RMB business has strengthened substantially since their government's introduction of a set of institutional measures supporting RMB use there.

A country's level of infrastructure favorable to RMB use is measured by examining whether it possesses the following five infrastructures, which are widely regarded as the main ones supporting RMB use: (i) Renminbi Qualified Foreign Institutional Investor (RQFII) scheme participation, (ii) an RMB-local currency bilateral currency swap arrangement with China, (iii) an offshore RMB clearing bank, (iv) direct trading between the domestic currency and the RMB, and (v) RMB-denominated reserves. ${ }^{15)}$

We adopt the end of November 2015, when the IMF announced inclusion of the RMB in the SDR currency basket, as the time standard for dividing the first users of the RMB from others. The selection of this point may be appropriate considering that the IMF decision was a symbolic milestone in formally recognizing the $\mathrm{RMB}$ as a consequential international currency, which may therefore lead foreigners, including central banks, to increase their uses of the

15) Although Liao and McDowell (2016) use the central bank's RMB holdings as their dependent variable in their analysis, they treat it as an indicator of RMB use rather than an infrastructure supporting that use. 
currency. In this context, the level of a country's RMB infrastructure is measured by analyzing how many out of the five RMB infrastructures that country had introduced by the end of November 2015.16)

To explain each of the five RMB infrastructures in detail, the RQFII, launched in 2011, permits licensed foreign investors to invest in equities and bonds in mainland China using offshore RMB. This scheme increases foreigners' RMB investment opportunities by providing them access to the mainland financial markets, thereby strengthening their motivations for holding RMB and in turn perhaps boosting their use of the RMB for payments as well. As of end-November 2015 there were a total of 14 countries participating in the RQFII scheme. ${ }^{17)}$

An RMB-local currency bilateral currency swap arrangement with China may help to increase a country's use of the RMB through two channels. It may be used first as a means for the country's acquisition of RMB to finance imports from China. Korea, for example, which became China's first bilateral RMB-local currency swap arrangement partner in December 2008, subsequently introduced a system in December 2012 that utilized the swap funds to supply local currency liquidity for trade settlement (Chey, 2015: 7). A country's currency swap arrangement with China may also strengthen its motivations for using the RMB by contributing to its financial stability, through facilitating the provision of foreign exchange liquidity during times of crisis (Chey, 2013a: 365). We identify only the countries that were maintaining currency swap arrangements at end-November 2015, excluding those that had established arrangements but not renewed them when their terms expired. For these latter countries may have signed currency swap agreements during the 2008 crisis as means chiefly of increasing their foreign exchange liquidity, without any strong intentions of

16) Eight economies-Australia, France, Hong Kong, Korea, Malaysia, Singapore, Switzerland and the United Kingdom - had all the five RMB infrastructures at the end of November 2015.

17) There is also the Qualified Foreign Institutional Investor (QFII) program, which allows licensed foreign investors to invest in securities and fixed incomes in mainland China by switching dollars into RMB. The introduction of this scheme goes back to 2003, however, far before the deliberate promotion of RMBI by the Chinese authorities began after the 2008 crisis. Also, since under this scheme foreign institutions switch dollars into RMB, it may not increase the demand for RMB use in foreign countries. This study consequently does not include the QFII in its list of the key RMB-related infrastructures used for analysis. 
promoting RMB use. As of end-November 2015 a total of 50 countries had RMB-local currency swap arrangements with China (when the 19 members of the eurozone countries are counted separately, considering that the European Central Bank holds one bilateral currency swap arrangement with China). ${ }^{18)}$

An offshore RMB clearing bank offers the clearing services for RMB transactions in a foreign region through its connections with the payment system of the People's Bank of China (PBoC), the Chinese central bank. It offers RMB liquidity to the banks participating in its clearing system, as well as administering their accounts, and in practice thereby plays the role of an offshore branch of the PBoC. Thus, the creation of an offshore RMB clearing bank substantially increases convenience in using the RMB and reduces the costs of settlement for RMB transactions (Chey, 2015: 12-13). As of end-November 2015 a total of 20 countries hosted offshore RMB clearing banks.

Direct trading of the RMB and another currency may help to augment RMB use in the country issuing that currency by lowering the transaction costs of using the RMB, since an intermediary currency (usually the dollar) is no longer required (Chey, 2015: 13). In fact, one year after the creation of a RMB-won direct trading market in Korea in December 2014, the average exchange commission in the country for an RMB-won transaction of one million dollars in value had fallen from 16,000 to 6,000 won, and the exchange rate spread on direct RMB-won trading was smaller than that on RMB-won trading through the arbitraged exchange rate using the dollar as the intermediary currency. In 2014 a direct trading market for the Kazakhstani Tenge and the RMB was also launched in Kazakhstan. In addition, as of end-November 2015 there were a total of 12 other currencies, one of them the euro, being directly traded in the China Foreign Exchange Trade System (CFETS). 19) At that time, therefore, with each of the 19 eurozone countries being counted individually, the domestic currencies of a total of 32 countries were being directly traded for the RMB.

18) Precisely speaking, a currency swap arrangement is between the People's Bank of China (PBoC) and a foreign central bank. And in our study, only those swap agreements that we have confirmed through official PBoC documents are identified.

19) Russia and Japan also have RMB-local currency direct trading markets in their countries, and their currencies are traded in the CFETS as well. 
Table 1. Numbers of Countries Having the Five RMB Infrastructures at End-November 2015

\begin{tabular}{l|c}
\multicolumn{1}{c|}{ Infrastructure } & Number of countries \\
RQF II & 14 \\
Bilateral currency swap & 50 \\
RMB clearing bank & 20 \\
RMB-domestic currency direct trading & 32 \\
RMB reserve holding & 38 \\
\hline Source: Compiled by authors based on data from the PBoC, the CFETS, the SAFE and various media
\end{tabular}

Although a central bank's holding of RMB reserves is one aspect of RMB use in the markets, it can also be regarded as one of the infrastructures supporting $\mathrm{RMB}$ use since the bank can then provide RMB liquidity to market actors, which may positively affect their incentives for using the RMB by increasing its convenience while also reducing its risks. As of end-November 2015 there were a total of 38 countries holding RMB reserves.

It is true that the establishment of all of these RMB-related infrastructures in a country is much affected by the inclination of the Chinese authorities to offer them to it. But even if the Chinese authorities wish to provide them, the country still has freedom to decide whether to accept them or not. A foreign government's own policy stance towards RMB use is therefore a key determinant of RMB usage in that country. Table 1 shows the numbers of countries equipped with each of the five different RMB infrastructures at the end of November 2015.

\section{Accounts of First Moves to the RMB}

Why are certain foreign governments determined to support RMB use in the early stage of its internationalization, when many others instead take wait-and-see approaches? In this section we discuss the factors that may affect foreign governments' support for RMB use. Distinct from the existing literature, we draw particular attention to the impact on a government's RMB use-related policy of its country's hosting of a major global financial center, a 
condition that is largely independent from the issuers of international currencies. Yet, extending on the literature, we do also consider the impacts of a country's relations, both economic and political, with the issuers of competing international currencies on its government's support for RMB use.

\section{Possession of a major global financial center}

As noted above, there have been a few recent studies addressing the determinants of currency internationalization from demand-side perspectives. However, even the majority of these stress mainly the relations between the user and the issuing countries, while paying little attention to the user countries' own domestic conditions that are essentially unaffected by these relations. Among various such conditions, this study calls special attention to the presence or absence of a major global financial center in a country, ultimately indicating the roles of global financial institutions and the related inter-state rivalries among international currency users in the rise of a new international currency.

A country's hosting of a major global financial center may have a positive impact on its government's policy toward the use of a newly-internationalizing currency, since global financial institutions operating in that country may demand policy support to promote their businesses related to the currency's use there. It has already been widely noted that domestic financial institutions in a country issuing an international currency can benefit substantially from that currency's international use, due to their competitive advantages in dealing in it.20) However, even certain groups of financial institutions from non-issuing countries, in particular those having strong global competitiveness, may benefit greatly from the emergence of a new international currency. This is because they may have capacities to develop businesses related to that currency earlier than others, and thus to dominate in advance the potentially lucrative new markets associated with it (Chey, 2012: 71, 2014: 49). A group of elite global banks such as HSBC, Standard Chartered, Citigroup and JPMorgan did in fact

20) See, for example, Cohen (2012a, 2015) and Swoboda (1968). 
hold international road shows to promote RMB use by their customers from immediately after RMBI began in the late 2000s. To this end they even offered financial incentives, including discounted transaction fees for trade settlement in the RMB (Chey, 2012: 71, 2014: 49). The probability of such financial institutions earning profits from the rise of a new international currency may be greater in a case where the global competitiveness of domestic financial institutions in the country issuing that currency is relative weak, which may be true of Chinese financial institutions related to RMBI.

A majority of large global financial institutions tend to have business operations in major global financial centers. The government of a country hosting such a center may thus face pressures from them to build the environment necessary for better RMB business. And to maintain or strengthen the competitiveness of its country as a global financial center, that government may respond favorably to such demand. One good example may be the United Kingdom, the home of London - a (or the) top global financial center in the world. The UK is at the very forefront in the global race to build offshore RMB financial centers. It holds all of the five RMB infrastructures discussed above. It moreover became in October 2014 the first western country to issue a sovereign bond in RMB, while one year later also becoming the first overseas financial center in which China issued RMB-denominated sovereign debt. Behind these UK policies have been strong pressures from financial institutions in that country to develop London as an offshore RMB financial center (Blitz, 2011a, $2011 b)$. Figure 1, in fact, indicates a quite strong positive relationship between countries' ratings in The Global Financial Centres Index 18 (Long Finance, 2015) and the numbers of RMB-related infrastructures found in them.

Exceptionally, even if it also hosts a primary global financial center the country issuing the incumbent key international currency may not respond favorably to demands from global financial institutions for development of infrastructures facilitating better use of a newly-emerging international currency. As has been widely noted, although it also generates some costs, having the dominant international currency brings substantial economic and political benefits to the issuing country-including international seigniorage, 
Figure 1. Relationship between Global Financial Center Index Rating and Level of RMB Infrastructure

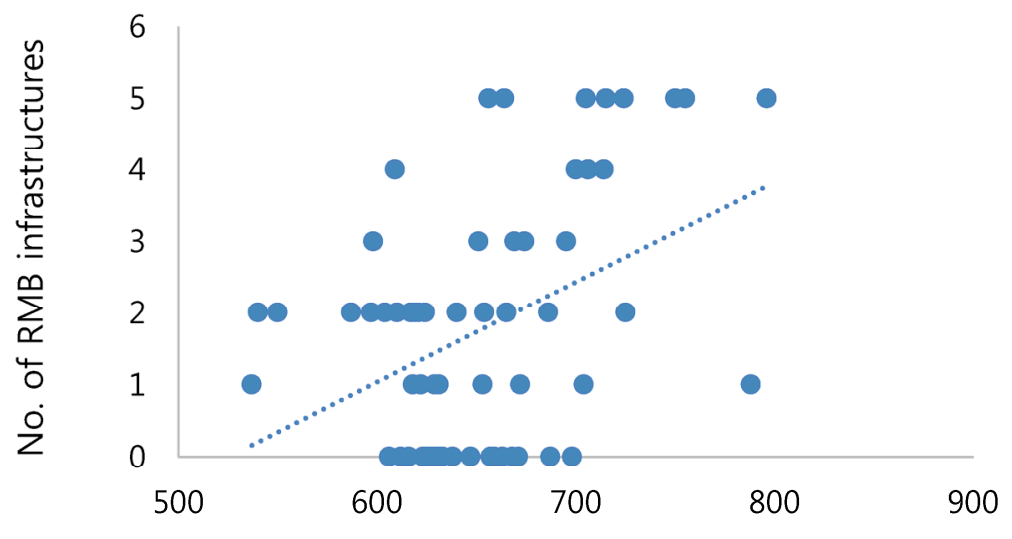

Global financial center index rating

Source: Global financial center index ratings from Long Finance (2015)

increased macroeconomic flexibility and strengthened international power (see Chey 2012, 2014; Cohen 2015). That country's government may therefore be reluctant to support use of a newly-internationalizing currency. And in connection with RMBI, this may be true of the United States. As of the end of November 2015 there was direct trading between the RMB and the dollar taking place (due to the latter's position as the leading international currency), but the US did not have any of the other four RMB infrastructures discussed above.

Even in the US, however, large global financial institutions-including those domiciled in the US - appear to be demanding an expansion of RMB use there (see Baer, 2015). In fact, although the US government had been slow to support RMB use in the country, it did recently (in June 2016) obtain an RQFII quota of 250 billion RMB (38 billion dollars), which will give US investors greater access to mainland Chinese markets. The size of the US RQFII quota is the second largest only after that of the UK. In addition to this measure, the United States and China have agreed to establish an RMB clearing bank in the United States (Yao and Lawder, 2016).

Given our analysis to this point, we draw our primary hypothesis as follows: 
Hypothesis 1: All other things being equal, a country having a major global financial center is likely to show a high level of RMB-related infrastructure.

\section{Economic relations with currency issuers}

Along with this principal hypothesis, we also explore two more hypotheses to analyze the impacts on a country's RMB infrastructure of its relations with countries issuing competing international currencies-one addressing its economic relations with them, and the other its political relations with them. As the international currency issuers we focus on China as well as on the United States, the issuer of the incumbent dominant international currency.

In analyzing a country's economic relations with the issuers of international currencies, we distinguish market-driven economic integration from policy-driven economic cooperation. A country's market-driven economic integration with a foreign country refers to its economic ties with that country that are driven by market forces, such as trade and investment. A good number of studies anticipate a positive association between such economic integration of one country with another issuing an international currency and the former country's use of that currency. As noted earlier, for instance, Liao and McDowell (2015) argue that countries having higher levels of economic integration with China tend to establish RMB-local currency bilateral currency swaps with China. Subramanian and Kessler (2012) contend that a country whose trade is deeply integrated with China is more likely to peg its currency to the RMB. Likewise, Dooley, Folkerts-Landau and Garber (2003) stress the economic considerations of governments in their selecting the anchor currencies to which they peg their currencies.

There are also some factors, however, that may lead us to question such an impact of a country's market-driven economic integration with China on its government's policy toward RMB use. As noted earlier, in this early stage of RMBI the costs of the currency's use are still substantial for most market actors. Therefore, even if the level of a country's economic interactions with China is high, its private sector demand for a strengthening of infrastructures supporting RMB use is likely to be limited (Chey, 2015). In addition, unlike the case with policy-driven economic cooperation, market-driven economic 
integration per se may not necessarily reflect the government's policy stance, implying no inevitable positive relationship between a government's RMB policy and its country's level of market-driven economic integration with China. On the other hand, a country's deep market-driven economic integration with the United States will probably not have greatly adverse impacts on its government's policy toward RMB use, since its dollar users will have little reason to demand suppression of the RMB. Given all of this, in contrast to the aforementioned existing studies, we have reservations about any substantial effects on a country's level of RMB-related infrastructure of its market driven economic integration with either China or the United States.

A country's policy-driven economic cooperation with a foreign country refers to its institutional agreements with that country, such as establishments of PTAs or BITs. Such economic cooperation with a foreign country may reflect the government's active intention to build stronger economic ties with that country. Liao and McDowell (2015) show, in fact, that the probability of a country signing a bilateral currency swap agreement with China is higher when it has a PTA or a BIT with China. We also expect a country's policy-driven economic cooperation with China to positively affect its government policy toward RMB use, and its economic cooperation with the United States to have the reverse effect.

We accordingly build the following hypothesis with regard to a country's economic relations with the issuers of the two competing international currencies:

Hypothesis 2: All other things being equal, while a country's depths of market-driven economic integration with China and the United States are not likely to significantly affect the level of its RMB-related infrastructure, the extents of its policy-driven economic cooperation with those countries will likely do so.

In measuring a country's levels of market-driven economic integration with China and the United States, this study will consider both its trade and investment reliance on them. For examination of a country's policy-driven economic cooperation with them, whether or not that country has PTAs or BITs with them will be considered. 


\section{Political relations with currency issuers}

A government's support for the use of a particular international currency may be motivated as well by its political policy goals, including its security-related ones.21) For the international use of a currency tends to strengthen the issuing state's international power through diverse channels, as a country's dependence on a certain international currency tends to increase its susceptibility to influence from the issuing state (Chey, 2012, 2014). One example is the recent United States imposition of aggressive financial sanctions against Iran to curb its nuclear program (Cohen, 2015). The ability of the US to provide dollar liquidity during a crisis may also augment its influence over countries that use the dollar (Chey, 2013b; Helleiner and Kirshner, 2009). Therefore, if a government wishes to maintain or to develop a good political relationship with a country issuing a particular international currency, it may support use of that currency. It is also likely that a country issuing an international currency may try to induce its allies to support the international use of its own currency and avoid using rival international currencies.

A good number of studies, including Cohen (2015), Helleiner (2008), Liao and McDowell (2015), Momani (2008) and Posen (2008), do in fact note that a country's security ties with foreign countries affect its use of international currencies. In addition, Liao and McDowell (2016) show that a country's ideological distances from China and the United States affect its central bank's choice of reserve currencies. ${ }^{22)}$ Given all of this, we build the following hypothesis regarding a country's political relations with the issuers of competing international currencies:

Hypothesis 3. All other things being equal, a country having strong political ties with China is likely to show a higher level of RMB-related infrastructure, whereas a country with close political connections to the US will tend to have a lower level of that infrastructure.

21) Helleiner (2008) argues that political factors can affect the internationalization of a currency both indirectly, through their impacts on the economic determinants of currency internationalization, and directly without regard to those economic determinants.

22) Yet, there are also a good number of studies noting a decline in the role of ideology in international politics since the end of the Cold War. See, for example, Calleo (2009), Eichengreen (2011a), Helleiner and Kirshner (2009) and Kirshner (2009). 
In testing this hypothesis we analyze a country's security relations and degrees of ideological closeness with China and the United States, and whether it has any territorial disputes with China as well.

\section{Data and Methodology}

The empirical subject of our study is RMBI. As RMBI is in its beginning stage currently, conducting research on it at this moment seems advantageous for identifying its first users. In our analysis, meanwhile, Hong Kong and Taiwan are treated as foreign regions vis-à-vis China.

\section{Dependent variable}

$R M B$ infrastructure. The dependent variable is the level of establishment of infrastructures supporting RMB use, which is measured on a three-point scale. If a country had introduced by the end of November 2015 three or more among the aforementioned five RMB infrastructures-(i) RQFII, (ii) a bilateral currency swap arrangement, (iii) an RMB clearing bank, (iv) RMB-domestic currency direct trading, and (v) holding of RMB reserves - it belongs to the category of those having 'strong infrastructure', which is coded 2.23) If a country held one or two among them at end-November 2015 it is categorized as having a 'weak infrastructure' and is coded 1. If it had no RMB infrastructure at that time then a country's category is 'no infrastructure', which is coded 0 . We adopt this three-scale categorization-instead of a six-scale one based on simply counting the numbers among the five total RMB-related infrastructures that a country holds - in order to reduce the differences in the numbers of countries across the categories while also minimizing any loss of information in our data. The data are from the PBoC, the CFETS, China's State Administration of

23) Hong Kong, the United Kingdom, Singapore, Korea, Switzerland, Australia, Malaysia, France, Canada, Chile, Germany, Hungary, Luxembourg, Argentina, Austria, Lithuania, Qatar, Russia, South Africa and Thailand belong to this category. 


\section{Table 2. Distribution of Countries for Dependent Variable}

\begin{tabular}{l|cc}
\multicolumn{1}{c|}{ Category } & Frequency & Percent \\
No infrastructure & 155 & 69.2 \\
Weak infrastructure & 49 & 21.9 \\
Strong infrastructure & 20 & 9.0 \\
\hline Total & 224 & 100.0 \\
\hline
\end{tabular}

Foreign Exchange (SAFE) and various media. Table 2 shows the numbers of countries belonging to the three categories:

\section{Primary explanatory variable}

Global financial center status. Our key explanatory variable is a country's status as a global financial center. We generate a categorical variable measured under a seven-point scale, based on countries' ranks in The Global Financial Centres Index 18 published by Long Finance in September 2015. This index measures the competitiveness of a city as a global financial center by taking into account 'instrumental factors', which provide objective evidence of competitiveness, as well as 'financial center assessments', which analyze responses to a questionnaire. The index includes 84 cities from 61 countries, with the cities rather than their countries being ranked. We rank a country on the basis of the rank given to its city. Where more than one city of a country are ranked in the index, the highest rank given is used. A country is coded 6 if it is ranked in the top ten, 5 if in the top 11 to 20,4 if in the top 21 to 30,3 if ranked in the top 31 to 40,2 if between 41 and 50, and 1 if ranked from 51 to 60 . A country that is unranked among the top 60 is given a code of 0 . The use of these categories has a substantial advantage in enabling an increased number of observations. ${ }^{24)}$ The variable is expected to positively affect the level of establishment of RMB infrastructure.

24) For instance, the use of countries' global financial center scores in the index reduces the number of observations in our empirical analyses to 51 . 


\section{Economic integration-related variables}

For analysis of the effects on a country's RMB-related infrastructure of its market-driven economic integrations with China and the United States, this study examines that country's levels of trade and investment reliance on them. The data on trade, investment and gross domestic product (GDP) are obtained, respectively, from the IMF's Direction of Trade Statistic (DOTS), from the United Nations Conference on Trade and Development (UNCTAD)'s bilateral FDI Statistics, and from the IMF's World Economic Outlook (WEO) database.

Trade reliance on China. The degree of a country's trade reliance on China is measured by the ratio to its GDP of the sum of its exports to and imports from China. The variable is not expected to have a significant impact on its level of RMB infrastructure.

Investment reliance on China. As the measure of a country's investment reliance on China, the ratio to GDP of the sum of its outstanding stocks of FDI to and from China is used. We do not expect this variable to significantly influence the country's RMB infrastructure level.

Trade reliance on the US. We use the ratio to its GDP of the sum of a country's exports to and imports from the United States in measuring its trade reliance on the US. The variable is not expected to affect its level of RMB infrastructure significantly.

Investment reliance on the US. The ratio to its GDP of the sum of a country's outstanding stocks of FDI to and from the United States is used to measure its investment reliance on the US. The effect of this variable on the RMB infrastructure level is anticipated to be insignificant. 


\section{Economic cooperation-related variables}

Meanwhile, a country's levels of policy-driven economic cooperation with China and the US are measured by considering its PTAs and BITs established with them. The data for this comes from China's Ministry of Commerce (MoC), the Asia Regional Integration Center of the Asian Development Bank (ADB), the Office of the United States Trade Representative (USTR), and UNCTAD.

PTA with China. We code it 1 if a country has a PTA with China, and 0 otherwise. This variable is expected to have a positive impact on the RMB infrastructure level.

BIT with China. A country with a BIT with China is coded 1, and a country without one 0 . We anticipate that the variable will affect the country's RMB infrastructure level favorably.

PTA with the US. We code 1 for a country having a PTA with the United States, and 0 for a country without one. The variable is expected to negatively influence the RMB infrastructure level.

BIT with the US. A country having a BIT with the United Sates is coded 1, while one without one is coded 0 . This variable is foreseen having an adverse impact on the RMB infrastructure level.

\section{Variables for political relations}

The effects on a country's RMB-related infrastructure due to its political relations with China and the United States are analyzed by examining its security ties with and ideological distances from China and the US, and also by considering its involvement in territorial disputes with China.

Security ties with China. Unlike the United States, China does not have any formal allies outside of North Korea. For the measurement of a country's 
security ties with China we therefore use as a proxy its membership in the Shanghai Cooperation Organization (SCO), an intergovernmental association for cooperation in political, economic and military affairs whose members include China and five other countries. ${ }^{25)}$ This proxy is in fact not an ideal one, given that the number of SCO member countries is quite small and also that all members excepting Russia are less developed countries in Central Asia. That being said, to our knowledge there is no better proxy available that can grasp a country's security relationship with China, and, indeed, some existing studies such as Liao and McDowell (2015) also use this variable. We follow them. The variable is a dichotomous one, coded 1 if a country holds SCO membership and 0 otherwise, based on data from the SOC. We expect it to positively affect a country's RMB infrastructure level.

Ideological distance from China. Following Liao and McDowell (2016), a country's ideological distance from China is measured using the Bailey, Strezhnev and Voeten (2015) data, which estimate countries' 'ideal points' by analyzing their voting behaviors in the United Nations General Assembly. This variable is expected to have a negative impact on the RMB infrastructure level.

Territorial dispute with China. This variable is a dichotomous one, with a coding of 1 if a country has a territorial dispute(s) with China and 0 otherwise, based on data obtained from the World Factbook of the US Central Intelligence Agency (CIA). It is anticipated to negatively affect the country's level of RMB infrastructure.

Security ties with the US. To measure a country's security ties with the United States, we examine whether it hosts a US military base. This variable is also dichotomous, coded 1 for a country having a US military base and 0 otherwise. The data is from Wikipedia. We expect the variable to have a negative effect on the RMB infrastructure level.

25) The five countries consist of Kazakhstan, Kyrgyzstan, Russia, Tajikistan and Uzbekistan. 
Our empirical analysis does not include a country's ideological distance from the US, considering that this has a very strong negative correlation (-0.86) with its ideological distance from China so that its inclusion could cause a multicollinearity problem.

\section{Control variables}

This research controls for the size of a country's ethnic Chinese population, the type of its exchange rate regime and the degree of its financial openness, given the potential effects of these factors on the dependent variable. We in addition control for a country's membership in the eurozone, considering that in constructing our dependent variable each of the eurozone member countries is treated individually.

Population of ethnic Chinese. We measure the size of the ethnic Chinese population in each country. The data is obtained from the 2013 Economic Year Book on Overseas Chinese published by the Overseas Community Affairs Council, a Taiwanese government agency. The variable is log-transformed, and a positive impact from it on the RMB infrastructure level is anticipated.

Exchange rate regime type. We identify a country's exchange rate regime using data from the 2014 Annual Report on Exchange Arrangements and Exchange Restrictions of the IMF (2014b). We adopt the coarse five-category classification employed by Rose (2014), rather than using the original ten categories in the IMF report, and code a country 5 if its exchange rate regime is a 'free floating' one, 4 if it adopts 'managed floating,' 3 if it employs a 'crawling peg', 2 if its exchange rate system is a 'conventional peg', and 1 if the exchange rate regime is a 'hard peg.' ${ }^{26)}$ This variable is expected to have a positive impact on the RMB infrastructure level.

26) The 'free floating', 'managed floating', and 'conventional peg' categories in Rose (2014) refer to the 'free floating', 'floating' and 'conventional peg' categories under the IMF classification, respectively, while Rose's 'crawling peg' includes the 'stabilized arrangement', 'crawling peg', 'crawl-like arrangement', 'pegged exchange rate within horizontal bands' and 'other managed arrangement' categories of the IMF. The 'hard peg' category in Rose (2014) encompasses the 'no separate legal tender' and 'currency board' IMF classifications. 
Financial openness. We examine the degree of a country's financial openness using the 2016 version of the Chinn-Ito Index (Chinn and Ito, 2006), which measures the level of a country's capital account openness up through 2014. The degree of financial openness in the original data is rescaled to be between 0 and 1 . We anticipate that the variable will positively influence the RMB infrastructure level.

Eurozone membership. This is a dummy variable. A country is coded 1 if it is a member of the eurozone, and 0 otherwise. The data is from the European Commission. Whether the association between this variable and the RMB infrastructure level is positive or negative is left up to our empirical analysis.

\section{Estimation method}

Given that our dependent variable has more than two categories, and that the values in each category have meaningful sequential orders, we run cross-country generalized ordered logistic regressions. For this study a cross-country analysis appears more appropriate than a longitudinal one, given that many of our explanatory variables, as well as the dependent variable, are institutional ones, whose values tend to remain stable for quite long times. We run generalized ordered logistic regressions by using the 'gologit2' command with the 'autofit' option in STATA 14, which identifies partial proportional odds models that fit the data.

We fit five models. Model 1 tests the impact of our key explanatory variable, 'global financial center status', on the dependent variable, controlling for all four control variables. Model 2 adds market-driven economic integration variables to Model 1, while Model 3 incorporates policy-driven economic cooperation variables. Model 4 adds political relations variables to Model 1 , and Model 5 includes all of the explanatory variables. These five models are therefore specified as follow:

Model 1. $\ln \left(\frac{\operatorname{Pr}(\mathrm{RMB} \text { inf. }>\mathrm{j})}{1-\operatorname{Pr}(\text { RMB inf. }>j)}\right)=\alpha_{j}+\beta_{1 j}$ global financial center status $+\beta_{2 j} Z$ 
Model 2. $\ln \left(\frac{\operatorname{Pr}(\mathrm{RMB} \text { inf. }>\mathrm{j})}{1-\operatorname{Pr}(R M B \text { inf. }>j)}\right)=\alpha_{j}+\beta_{1 j}$ global financial center status + $\beta_{2 j}$ trade reliance on China $+\beta_{3 j}$ investment reliance on China $+\beta_{4 j}$ trade reliance on US $+\beta_{5 j}$ investment reliance on US $+\beta_{6 j} Z$

Model 3. $\ln \left(\frac{\operatorname{Pr}(\mathrm{RMB} \text { inf. }>\mathrm{j})}{1-\operatorname{Pr}(\text { RMB inf. }>j)}\right)=\alpha_{j}+\beta_{1 j}$ global financial center status + $\beta_{2 j}$ PTA with China $+\beta_{3 j}$ BIT with China + $\beta_{4 j}$ PTA with US $+\beta_{5 j}$ BIT with US $+\beta_{6 j} Z$

Model 4. $\ln \left(\frac{\operatorname{Pr}(\mathrm{RMB} \text { inf. }>\mathrm{j})}{1-\operatorname{Pr}(\text { RMB inf. }>j)}\right)=\alpha_{j}+\beta_{1 j}$ global financial center status + $\beta_{2 j}$ security ties with China $+\beta_{3 j}$ ideological distance from China $+\beta_{4 j}$ territorial dispute with China $+\beta_{5 j}$ security ties with US $+\beta_{6 j} Z$

Model $5 . \ln \left(\frac{\operatorname{Pr}(\mathrm{RMB} \text { inf } .>\mathrm{j})}{1-\operatorname{Pr}(R M B \text { inf. }>j)}\right)=\alpha_{j}+\beta_{1 j}$ global financial center status + $\beta_{2 j}$ trade reliance on China $+\beta_{3 j}$ investment reliance on China $+\beta_{4 j}$ trade reliance on $\mathrm{US}+\beta_{5 j}$ investment reliance on US + $\beta_{6 j}$ PTA with China $+\beta_{7 j}$ BIT with China $+\beta_{8 j}$ PTA with US $+\beta_{9 j}$ BIT with US + $\beta_{10 j}$ security ties with China + $\beta_{11 j}$ ideological distance from China + $\beta_{12 j}$ territorial dispute with China + $\beta_{13 j}$ security ties with US $+\beta_{14 j} Z$

where $\operatorname{Pr}(R M B$ inf. $>j)$ denotes the probability of 'RMB infrastructure' being greater than $j$, which takes 0 or 1 , and $\mathrm{Z}$ is a vector of four control variables. 


\section{Empirical Results}

\section{Major findings}

Our analysis finds that the variables of 'global financial center status' and 'security ties with the US' violate the proportional odds assumption in Models 4 and 5, while that of 'exchange rate regime type' does so in all five models. ${ }^{27)} \mathrm{We}$ also run a variance inflation factor (VIF) test to detect any multicollinearity problem, and find the VIF values of all explanatory variables to range from 1.03 to 1.97 with their mean being 1.52 , thus suggesting weak multicollinearity among the variables.

Table 3 summarizes our results for the five model specifications. For a variable that violates the proportional odds assumption, two sets of a coefficient and a standard error are reported vertically; the coefficient and the standard error in the upper row can be interpreted as those from a binary logit regression where the dependent variable is recoded as 'no infrastructure' versus 'weak infrastructure' plus 'strong infrastructure', and those in the lower row as from a binary logit regression where the dependent variable is recoded as 'no infrastructure' plus 'weak infrastructure' versus 'strong infrastructure'.

Our results strongly support our primary hypothesis (Hypothesis 1) expecting a positive relationship between the hosting of a major global financial center and the level of RMB-related infrastructure establishment. 'Global financial center status' has positive and strongly significant impacts on the dependent variable through all five models. In Models 4 and 5 its coefficients grow larger across the cutpoints, meaning that a country hosting a more highly-ranked global financial center is more likely to belong in the 'strong RMB infrastructure' category. We also estimate the predicted probabilities of RMB infrastructure establishment for various values of 'global financial center status' in Model 5. The predicted probability of a country belonging in the 'strong infrastructure' category is found to be 0.81 if it has a top ten global

27) The proportional odds assumption for an ordered logistic model is the assumption that the coefficients for each explanatory variable are equal across all levels of the dependent variable. 
financial center, and 0.65 if it has one in the top 11 to 20 . That probability falls to 0.05 for global financial centers ranked between 51 and 60 and to 0.02 for those ranked below 60. Meanwhile, the predicted probabilities of inclusion in the 'no infrastructure' category are 0.67 and 0.60 for countries whose global financial center standings are below 60 and between 51 to 60 respectively, while dropping to 0.25 and 0.32 respectively for global financial centers in the top ten and the top 11 to 20. All of the predicted probabilities are statistically significant.

The regression results also largely support Hypothesis 2 that addresses the impact of market-driven economic integration and policy-driven economic cooperation on RMB-related infrastructures. Concerning market-driven economic integration, as anticipated, neither trade nor investment reliance on China or on the United States have significant effects on the levels of RMB infrastructure. In contrast, policy-driven economic cooperation with China, through having either a PTA or a BIT with the country, or both, shows significant positive impacts on the dependent variable in both Models 3 and 5 . Meanwhile, the effects on its RMB infrastructure of a country's PTA or its BIT with the United States are not statistically significant, although as foreseen the signs of their coefficients are negative.

With regard to Hypothesis 3, which concerns the association between a country's political relations with China and the United States and its RMB infrastructure, our empirical analysis shows some, albeit limited, support as well. On the one hand, the significant negative coefficients for 'security ties with the US' in the lower rows in both Models 4 and 5 suggest that, as anticipated, a country hosting a US military base is less likely to be in the 'strong RMB infrastructure' category. On the other hand, however, none of the remaining political relations variables show significant impacts in these two models, although the signs of their coefficients are all in accord with our expectations.

As to the control variables, a country's ethnic Chinese population and the degree of its financial openness have no significant impacts on the level of its RMB-related infrastructure through all five models. 'Exchange rate regime type' meanwhile shows a significant positive effect in all models, in the upper 
rows in particular, meaning that a country having more of a floating regime is likely to belong in the 'weak infrastructure' or the 'strong infrastructure' categories rather than in the 'no infrastructure' one. A country's membership in the eurozone positively and significantly affects the level of its RMB infrastructure in all models as well. 


\section{$31 \quad$ BOK Working Paper No. 2016-19}

Table 3. Factors Affecting Level of a Country's RMB Infrastructure

\begin{tabular}{|c|c|c|c|c|c|}
\hline & Model 1 & Model 2 & Model 3 & Model 4 & Model 5 \\
\hline Global financial center status & $\begin{array}{l}0.618^{* * *} \\
(0.130)\end{array}$ & $\begin{array}{l}0.611^{* * *} \\
(0.131)\end{array}$ & $\begin{array}{l}0.660^{* * *} \\
(0.137)\end{array}$ & $\begin{array}{l}0.363^{* *} \\
(0.160) \\
0.965^{* * *} \\
(0.203)\end{array}$ & $\begin{array}{l}0.417^{* *} \\
(0.171) \\
1.034^{* * *} \\
(0.211)\end{array}$ \\
\hline Trade reliance on China & & $\begin{array}{l}0.004 \\
(0.014)\end{array}$ & & & $\begin{array}{l}-0.009 \\
(0.018)\end{array}$ \\
\hline Investment reliance on China & & $\begin{array}{l}-0.001 \\
(0.002)\end{array}$ & & & $\begin{array}{l}-0.001 \\
(0.002)\end{array}$ \\
\hline Trade reliance on US & & $\begin{array}{l}-0.029 \\
(0.026)\end{array}$ & & & $\begin{array}{l}-0.017 \\
(0.030)\end{array}$ \\
\hline Investment reliance on US & & $\begin{array}{l}-0.001 \\
(0.004) \\
\end{array}$ & & & $\begin{array}{l}-0.001 \\
(0.005) \\
\end{array}$ \\
\hline PTA with China & & & $\begin{array}{l}1.223^{*} \\
(0.625)\end{array}$ & & $\begin{array}{l}1.465^{*} \\
(0.755)\end{array}$ \\
\hline BIT with China & & & $\begin{array}{l}0.877^{*} \\
(0.490)\end{array}$ & & $\begin{array}{l}0.902^{*} \\
(0.512)\end{array}$ \\
\hline PTA with US & & & $\begin{array}{l}-0.971 \\
(0.713)\end{array}$ & & $\begin{array}{l}-0.841 \\
(0.778)\end{array}$ \\
\hline BIT with US & & & $\begin{array}{l}-0.467 \\
(0.493)\end{array}$ & & $\begin{array}{l}-0.561 \\
(0.510)\end{array}$ \\
\hline Security ties with China & & & & $\begin{array}{l}1.207 \\
(0.925)\end{array}$ & $\begin{array}{l}1.008 \\
(1.008)\end{array}$ \\
\hline Ideological distance from China & & & & $\begin{array}{l}-0.198 \\
(0.347)\end{array}$ & $\begin{array}{l}-0.193 \\
(0.363)\end{array}$ \\
\hline Territorial dispute with China & & & & $\begin{array}{l}-0.045 \\
(0.808)\end{array}$ & $\begin{array}{l}-1.193 \\
(0.932)\end{array}$ \\
\hline Security ties with US & & & & $\begin{array}{l}0.565 \\
(0.720) \\
-1.485^{*} \\
(0.814)\end{array}$ & $\begin{array}{l}0.699 \\
(0.811) \\
-1.447^{*} \\
(0.875) \\
\end{array}$ \\
\hline Population of ethnic Chinese & $\begin{array}{l}0.043 \\
(0.040)\end{array}$ & $\begin{array}{l}0.056 \\
(0.042)\end{array}$ & $\begin{array}{l}-0.006 \\
(0.049)\end{array}$ & $\begin{array}{l}0.055 \\
(0.043)\end{array}$ & $\begin{array}{l}0.011 \\
(0.053)\end{array}$ \\
\hline Exchange rate regime type & $\begin{array}{l}0.716^{* * *} \\
(0.216) \\
-0.079 \\
(0.273)\end{array}$ & $\begin{array}{l}0.662^{* * *} \\
(0.219) \\
-0.119 \\
(0.276)\end{array}$ & $\begin{array}{l}0.594^{* *} \\
(0.236) \\
-0.118 \\
(0.293)\end{array}$ & $\begin{array}{l}0.747^{* * *} \\
(0.232) \\
-0.270 \\
(0.321)\end{array}$ & $\begin{array}{l}0.624^{* *} \\
(0.252) \\
-0.318 \\
(0.342)\end{array}$ \\
\hline Financial openness & $\begin{array}{l}-0.924 \\
(0.576)\end{array}$ & $\begin{array}{l}-0.887 \\
(0.588)\end{array}$ & $\begin{array}{l}-0.613 \\
(0.614)\end{array}$ & $\begin{array}{l}-0.746 \\
(0.611)\end{array}$ & $\begin{array}{l}-0.545 \\
(0.683)\end{array}$ \\
\hline Eurozone membership & $\begin{array}{l}1.703^{* *} \\
(0.719)\end{array}$ & $\begin{array}{l}1.711^{* *} \\
(0.724)\end{array}$ & $\begin{array}{l}1.610^{* *} \\
(0.748)\end{array}$ & $\begin{array}{l}2.278^{* * *} \\
(0.846)\end{array}$ & $\begin{array}{l}2.056^{* *} \\
(0.861)\end{array}$ \\
\hline $\begin{array}{l}\text { Observations } \\
\text { Pseudo R2 }\end{array}$ & $\begin{array}{l}170 \\
0.287\end{array}$ & $\begin{array}{l}168 \\
0.293\end{array}$ & $\begin{array}{l}170 \\
0.328\end{array}$ & $\begin{array}{l}169 \\
0.321\end{array}$ & $\begin{array}{l}168 \\
0.366\end{array}$ \\
\hline
\end{tabular}

Notes: Standard errors in parentheses. ${ }^{*}{ }^{* *}$ and $* * *$ denote significances at the $10 \%, 5 \%$ and $1 \%$ levels respectively. 


\section{Robustness checks}

To probe the soundness of our empirical findings, we conduct a series of robustness checks by fitting six additional models. Table 4 shows the robustness check results.

In Models 6, 7 and 8 we employ an alternate dependent variable that simply counts the number among the five total RMB-related infrastructures that a country holds,28) and at the same time adopt Ordinary Least Squares regression as an alternative method of estimation. In addition, while the standard measure of global financial center status used for Models 1 to 5 is adopted in Model 6, alternate measures are employed for Models 7 and 8. Model 7 uses country scores in The Global Finance Centres Index 18 (Long Finance, 2015) as an alternate global financial center status measure. And then in Model 8, given that a global financial center tends to have a developed financial system, we employ as an alternate measure country scores from the 'Financial Development Index' in The Financial Development Report 2012 issued by the World Economic Forum (2012). This index measures financial development by analyzing the institutional environment, business environment, level of financial stability, extent of banking and non-banking financial services, level of financial market development and degree of financial access.29) Model 6 tests all explanatory variables used in Model 5, while Models 7 and 8 include only those that showed significant impacts in at least one of the original five models, since inclusion of irrelevant variables would reduce the precision of the coefficients estimated for the relevant variables, especially given the small numbers of observations in those two models.

In Model 9 we run the same regression analysis as that adopted in Model 5, but with eurozone member countries excluded from our dataset given the

28) The values of the dependent variable hence range from 0 to 5 in those models.

29) We do not use the two alternate measures of global financial center status in a model adopting an ordered logistic regression, since their use would reduce the number of observations considerably - to 51 and 61 in Models 7 and 8, respectively, as shown in Table 4. A significance test for a sample of less than 100 is risky in a logistic regression, as little is known about the small sample properties of logistic regression coefficients (Pampel, 2000: 30). 
concern that our treatment of those countries in constructing our dependent variable might distort the results. In Model 10 we again implement the same regression analysis as that used in Model 5 , but this time excluding all of the 25 offshore financial centers identified by the IMF (2014a). This is because their inclusion might cause a misleading outcome, as most of them have minimal capacities for building the aforementioned RMB-related infrastructures while nevertheless tending to obtain high ranks as global financial centers. While all of the explanatory variables meet the proportional odds assumption in Model 9, 'global financial center status', 'security ties with the US' and 'exchange rate regime type' violate it in Model 10.

Throughout all Models 6 to 10, 'global financial center status' still has significant and positive impacts on the RMB infrastructure, while its coefficients grow large across the cutpoints in Model 10. A country's PTA with China also significantly and positively affects its RMB-related infrastructure in all of these five models. In addition, although a 'BIT with China' does not show a significant impact in any of the models, its p-value is actually quite close to the borderline of a 10 percent significance level in four of them, marking 0.160 in Model 6, 0.115 in Model 7, 0.108 in Model 9 and 0.155 in Model 10. None of the four political relations variables-including a country's security ties with the United States - show significant impacts, however, and none of the economic integration-related variables do either.

Finally, in Model 11, we employ a country's holding of RMB reserves alone as our alternate dependent variable, considering that Liao and McDowell (2016) used it as the dependent variable of their study. In this model we use the standard measure of global financial center status and run a binary logistic regression, including both eurozone member countries and offshore financial centers. A country is coded 1 if it has RMB reserve holdings and 0 otherwise. In this model as well, 'global financial center status' has a significant positive effect on the alternate dependent variable. Additionally, similar to our anticipations, a country's BIT with China has a significant positive effect on the dependent variable in this model, while its having a BIT with the United States shows a significant negative impact. None of the remaining explanatory variables have any significant influence on the dependent variable. 
Table 4. Alternate Estimations

\begin{tabular}{|c|c|c|c|c|c|c|}
\hline & Model 6 & Model 7 & Model 8 & Model 9 & Model 10 & Model 11 \\
\hline $\begin{array}{l}\text { Global financial center } \\
\text { status }\end{array}$ & $\begin{array}{l}0.364^{* * *} \\
(0.054)\end{array}$ & $\begin{array}{l}0.018^{* * *} \\
(0.004)\end{array}$ & $\begin{array}{l}1.034^{* * *} \\
(0.253)\end{array}$ & $\begin{array}{l}0.627^{* * *} \\
(0.167)\end{array}$ & $\begin{array}{l}0.423^{* *} \\
(0.176) \\
1.017^{* * *} \\
(0.214)\end{array}$ & $\begin{array}{l}0.329^{* *} \\
(0.155)\end{array}$ \\
\hline Trade reliance on China & $\begin{array}{l}-0.000 \\
(0.005)\end{array}$ & & & $\begin{array}{l}-0.005 \\
(0.017)\end{array}$ & $\begin{array}{l}-0.013 \\
(0.019)\end{array}$ & $\begin{array}{l}-0.017 \\
(0.027)\end{array}$ \\
\hline Investment reliance on & -0.000 & & & -0.001 & 0.020 & -0.001 \\
\hline $\begin{array}{l}\text { China } \\
\text { Trade reliance on US }\end{array}$ & $\begin{array}{l}(0.000) \\
-0.002 \\
(0.009)\end{array}$ & & & $\begin{array}{l}(0.003) \\
-0.002 \\
(0.029)\end{array}$ & $\begin{array}{l}(0.022) \\
-0.007 \\
(0.032)\end{array}$ & $\begin{array}{l}(0.002) \\
-0.045 \\
(0.037)\end{array}$ \\
\hline $\begin{array}{l}\text { Investment reliance on } \\
\text { US }\end{array}$ & $\begin{array}{l}-0.000 \\
(0.000)\end{array}$ & & & $\begin{array}{l}-0.001 \\
(0.005)\end{array}$ & $\begin{array}{l}-0.016 \\
(0.022)\end{array}$ & $\begin{array}{l}-0.000 \\
(0.002)\end{array}$ \\
\hline PTA with China & $\begin{array}{l}0.957^{* * *} \\
(0.292)\end{array}$ & $\begin{array}{l}1.610^{* * *} \\
(0.507)\end{array}$ & $\begin{array}{l}1.237^{* *} \\
(0.482)\end{array}$ & $\begin{array}{l}1.525^{* *} \\
(0.704)\end{array}$ & $\begin{array}{l}1.542^{* *} \\
(0.755)\end{array}$ & $\begin{array}{l}-0.065 \\
(0.804)\end{array}$ \\
\hline BIT with China & $\begin{array}{l}0.266 \\
(0.189)\end{array}$ & $\begin{array}{l}0.989 \\
(0.616)\end{array}$ & $\begin{array}{l}0.205 \\
(0.562)\end{array}$ & $\begin{array}{l}0.851 \\
(0.529)\end{array}$ & $\begin{array}{l}0.739 \\
(0.520)\end{array}$ & $\begin{array}{l}1.351^{* *} \\
(0.607)\end{array}$ \\
\hline PTA with US & $\begin{array}{l}0.013 \\
(0.261)\end{array}$ & & & $\begin{array}{l}-0.164 \\
(0.771)\end{array}$ & $\begin{array}{l}-0.838 \\
(0.786)\end{array}$ & $\begin{array}{l}-0.305 \\
(0.817)\end{array}$ \\
\hline BIT with US & $\begin{array}{l}-0.251 \\
(0.182)\end{array}$ & & & $\begin{array}{l}-0.768 \\
(0.540)\end{array}$ & $\begin{array}{l}-0.556 \\
(0.513)\end{array}$ & $\begin{array}{l}-1.444^{* *} \\
(0.706)\end{array}$ \\
\hline Security ties with China & $\begin{array}{l}0.604 \\
(0.441)\end{array}$ & & & $\begin{array}{l}1.131 \\
(1.019)\end{array}$ & $\begin{array}{l}1.132 \\
(1.019)\end{array}$ & $\begin{array}{l}-0.453 \\
(1.270)\end{array}$ \\
\hline $\begin{array}{l}\text { Ideological distance } \\
\text { from China }\end{array}$ & $\begin{array}{l}0.056 \\
(0.138)\end{array}$ & & & $\begin{array}{l}-0.383 \\
(0.369)\end{array}$ & $\begin{array}{l}-0.122 \\
(0.376)\end{array}$ & $\begin{array}{l}-0.674 \\
(0.448)\end{array}$ \\
\hline $\begin{array}{l}\text { Territorial dispute with } \\
\text { China }\end{array}$ & $\begin{array}{l}-0.170 \\
(0.380)\end{array}$ & & & $\begin{array}{l}-1.443 \\
(0.918)\end{array}$ & $\begin{array}{l}-1.405 \\
(0.972)\end{array}$ & $\begin{array}{l}0.330 \\
(0.989)\end{array}$ \\
\hline Security ties with US & $\begin{array}{l}-0.107 \\
(0.246)\end{array}$ & $\begin{array}{l}-0.196 \\
(0.423)\end{array}$ & $\begin{array}{l}-0.265 \\
(0.444)\end{array}$ & $\begin{array}{l}0.206 \\
(0.769)\end{array}$ & $\begin{array}{l}0.783 \\
(0.816) \\
-1.194 \\
(0.875)\end{array}$ & $\begin{array}{l}-0.805 \\
(0.762)\end{array}$ \\
\hline $\begin{array}{l}\text { Population of ethnic } \\
\text { Chinese }\end{array}$ & $\begin{array}{l}0.001 \\
(0.019)\end{array}$ & & & $\begin{array}{l}0.002 \\
(0.054)\end{array}$ & $\begin{array}{l}0.001 \\
(0.054)\end{array}$ & $\begin{array}{l}0.111^{*} \\
(0.058)\end{array}$ \\
\hline $\begin{array}{l}\text { Exchange rate regime } \\
\text { type }\end{array}$ & $\begin{array}{l}0.060 \\
(0.080)\end{array}$ & $\begin{array}{l}-0.036 \\
(0.193)\end{array}$ & $\begin{array}{l}0.116 \\
(0.195)\end{array}$ & $\begin{array}{l}0.655^{* *} \\
(0.256)\end{array}$ & $\begin{array}{l}0.640^{* *} \\
(0.257) \\
-0.238 \\
(0.351)\end{array}$ & $\begin{array}{l}0.097 \\
(0.279)\end{array}$ \\
\hline Financial openness & $\begin{array}{l}-0.056 \\
(0.239)\end{array}$ & & & $\begin{array}{l}-0.413 \\
(0.669)\end{array}$ & $\begin{array}{l}-0.554 \\
(0.696)\end{array}$ & $\begin{array}{r}-0.822 \\
(0.842)\end{array}$ \\
\hline Eurozone membership & $\begin{array}{l}1.222^{* * *} \\
(0.294)\end{array}$ & $\begin{array}{l}1.776^{* * *} \\
(0.543)\end{array}$ & $\begin{array}{l}0.675 \\
(0.552)\end{array}$ & & $\begin{array}{l}2.194^{* *} \\
(0.921)\end{array}$ & $\begin{array}{l}-0.606 \\
(0.925)\end{array}$ \\
\hline $\begin{array}{l}\text { Observations } \\
\text { Adjusted R2 } \\
\text { Pseudo R2 }\end{array}$ & $\begin{array}{l}168 \\
0.524\end{array}$ & $\begin{array}{l}51 \\
0.399\end{array}$ & $\begin{array}{l}61 \\
0.313\end{array}$ & $\begin{array}{l}151 \\
0.287\end{array}$ & $\begin{array}{l}161 \\
0.352\end{array}$ & $\begin{array}{l}168 \\
0.235\end{array}$ \\
\hline
\end{tabular}

Notes: Standard errors in parentheses. ${ }^{*}, *$ and $* * *$ denote significances at the $10 \%, 5 \%$ and $1 \%$ levels respectively. 


\section{Conclusion}

Internationalization of a country's currency means by definition its use by foreigners, and the foreign users of a currency thus ultimately determine its internationalization. It is especially the first users of a newly-internationalizing currency that drive and lead its rise to consequence, thereby shaping the emergence of a new international monetary order. The issue of who are the first users of a newly-internationalizing currency has remained significantly underexplored, however, despite the recent revitalized keen interest in the study of currency internationalization since the global financial crisis. The majority of the existing studies have placed their analytic focuses mainly on the international currency issuers, thus adopting supply-side approaches, in examining the determinants of currency internationalization. In contrast to them, by employing a demand-side analysis concentrating on the users of international currencies, this study has addressed the crucial issue of who the first users of a newly-internationalizing currency are, with a particular focus on the case of the Chinese RMB, whose international use has grown remarkably in recent years.

In accounting for the first users of the RMB, this research has shed special light on the positive impact of the presence of a major global financial center in a country on its government's policy toward RMB use, thus ultimately highlighting the roles of global financial institutions and the associated inter-state rivalries among international currency users in the emergence of a new international currency. Along with this primary finding, our study has also found a strong positive impact of a country's institutional economic cooperation with China, through a PTA or a BIT, on its government's policy regarding use of the RMB. Our analysis has in addition shown some support for a negative association between a country's security ties with the United States and its use of the Chinese currency. Meanwhile, and contrary to the prevailing anticipations in the literature, we have found as well that on the whole a country's market-driven economic integration with either China or the United States does not substantially affect its government's policy toward RMB use. In this 
regard it should however be stressed that we do not claim that a country's market-driven economic integration with China is totally irrelevant to its RMB use. A country having considerable economic interactions with China may eventually increase its use of the RMB. Yet, this may happen only after internationalization of the RMB has reached a consequential level. In this very early stage of RMB internationalization, where the transaction costs of using the RMB remain significantly high, a country's mere economic interactions with China do not necessarily lead to an increase in its RMB use, or more precisely in its establishment of strong RMB-related infrastructure. All of these findings explicate the question of which factors motivate the use of a newlyinternationalizing currency.

Our study also makes significant contributions to the broader research on the mechanisms behind the structural changes in the world political economy, by explaining who are more likely to accommodate a newly-rising international monetary power and why they are likely to do so.

The findings in this research can provide useful policy implications as well for emerging economies pursuing expansions in the international uses of their currencies. First, where a currency obtains strong support for its international use from major global financial centers, its internationalization may be more successful. Such support from global financial centers for a currency's international use does however appear to be based upon foreign users' anticipation that its internationalization will reach a substantial level. If an emerging economy currency is to generate such an expectation, well-designed and active policies by its authorities for promotion of its internationalization are likely to be needed, considering that, even despite China's status as the world's leading exporter and second largest economy, meaningful internationalization of the RMB began to take place only after the introduction by the Chinese authorities of extensive policy measures to promote its internationalization.

It also appears to be a more effective policy strategy to aim at bolstering a currency's international use in a foreign country that has policy-driven economic cooperation with the issuing country, rather than in one having mere market-driven economic interactions with it. In other words, a country's 
facilitation of PTAs or BITs with other countries, for example, will likely serve as useful steppingstones to higher international usage of its currency in the future.

Meanwhile, the finding in this study with regard to the adverse effect of a country's security ties with the United States on its RMB use might not be applicable to many other emerging economies' cases, going beyond the Chinese one. Most emerging economies do not appear to be involved in such delicate strategic rivalries with the United States, encompassing economic cooperation and competition as well as political confrontation, as is the case with China at present.

Finally, future research on RMB usage in individual countries, through comparative studies or single case analyses, can be expected to complement the findings of this study. For instance, an in-depth comparative analysis of the interactions between global financial institutions and governments regarding RMBI across the major countries such as the United Kingdom and the United States would be an intriguing subject. 


\section{References}

Baer, J. (2015), "Wall Street Group Pushes Trading of China's Yuan in U.S.," The Wall Street Journal, November 29.

Bailey, M. A., A. Strezhnev, and E. Voeten (2015), "Estimating Dynamic State Preferences from United Nations Voting Data," Journal of Conflict Resolution, DOI: 10.1177/0022002715595700.

Blitz, J. (2011a), "Britain and China Strengthen Relations," Financial Times, September 8 .

(2011b), "China to Back London as Offshore Renminbi Centre," Financial Times, September 7.

Bowles, P. and B. Wang (2008), "The Rocky Road Ahead: China, the US and the Future of the Dollar," Review of International Political Economy, Vol. 15(3), pp. 335-353.

Broz, J. L. (1997), The International Origins of the Federal Reserve System, Ithaca, NY: Cornell University Press.

Calleo, D. P. (2009), "Twenty-First Century Geopolitics and the Erosion of the Dollar Order," in E. Helleiner and J. Kirshner (eds.) The Future of the Dollar, Ithaca, NY: Cornell University Press, pp. 164-190.

Chey, H.-k. (2012), "Theories of International Currencies and the Future of the World Monetary Order," International Studies Review, Vol. 14(1), pp. 51-77.

(2013a), "Can the Renminbi Rise as a Global Currency? The Political Economy of Currency Internationalization," Asian Survey, Vol. 53(2), pp. 348-368.

(2013b), "The Fed Swap Lines and the Global Lender of Last Resort: The Politics of International Monetary Relations," paper presented at 2013 American Political Science Association Annual Meeting, Chicago, IL, August 29 to September 1, 2013.

(2014), "The Political Economy of Currency Internationalization," in T. Oatley and W. K. Winecoff (eds.) Handbook of the International Political Economy of Monetary Relations, Cheltenham and Northampton: Edward Elgar Publishing, pp. 39-53. 
(2015), "Renminbi in Ordinary Economies: A Demand-Side Study of Currency Globalization," China \& World Economy, Vol. 23(3), pp. 1-21.

Chey, H.-k. and Y. W. V. Li (2016), "Bringing the Central Bank into the Study of Currency Internationalization: Monetary Policy, Independence, and Internationalization," paper prepared for 2016 International Studies Association Annual Convention, Atlanta, GA, March 16 to 19, 2016.

Chinn, M. and J. A. Frankel (2007), "Will the Euro Eventually Surpass the Dollar as Leading International Reserve Currency?" in R. H. Clarida (ed.) G7 Current Account Imbalances: Sustainability and Adjustment, Chicago: University of Chicago Press, pp. 283-338.

Chinn, M. D. and H. Ito (2006), "What Matters for Financial Development? Capital Controls, Institutions, and Interactions," Journal of Development Economics, Vol. 81(1), pp. 163-192.

Cohen, B. J. (1971), The Future of Sterling as an International Currency, London: Macmillan.

(1998), The Geography of Money, Ithaca, NY: Cornell University Press.

(2009), "Dollar Dominance, Euro Aspirations: Recipe for Discord?" Journal of Common Market Studies, Vol. 47(4), pp. 741-766.

(2012a), "The Benefits and Costs of an International Currency: Getting the Calculus Right," Open Economies Review, Vol. 23(1), pp. 13-31.

(2012b), "The Yuan Tomorrow? Evaluating China's Internationalization Strategy," New Political Economy, Vol. 17(3), pp. 361-371.

(2015), Currency Power: Understanding Monetary Rivalry, Princeton, NJ: Princeton University Press.

Cohen, B. J. and T. Benney (2014), "What Does the International Currency System Really Look Like?" Review of International Political Economy, Vol. 21(5), pp. 1017-1041.

Despres, E., C. P. Kindleberger, and W. S. Salant (1965), "The Dollar and World Liquidity: A Minority View," The Economist, February 5, pp 526-529. 
Dooley, M. P., D. Folkerts-Landau, and P. Garber (2003), "An Essay on the Revived Bretton Woods System," NBER Working Paper No. 9971, National Bureau of Economic Research, Cambridge, MA.

Dooley, M. P., J. S. Lizondo, and D. J. Mathieson (1989), "The Currency Composition of Foreign Exchange Reserves," Staff Papers (International Monetary Fund), Vol. 36(2), pp. 385-434.

Eichengreen, B. (2011a), Exorbitant Privilege: The Rise and Fall of the Dollar and the Future of the International Monetary System, Oxford: Oxford University Press.

(2011b), "The Renminbi as an International Currency," Journal of Policy Modeling, Vol. 33(5), pp. 723-730.

(2013), "Number One Country, Number One Currency," The World Economy, Vol. 36(4), pp. 363-374.

Eichengreen, B. and M. Kawai (2014), "Issues for Renminbi Internationalization: An Overview," ADBI Working Paper No. 454, Asian Development Bank Institute, Tokyo.

Eichengreen, B. and D. Lombardi (2015), "RMBI or RMBR: Is the Renminbi Destined to Become a Global or Regional Currency?" NBER Working Paper No. 21716, National Bureau of Economic Research, Cambridge, MA.

Frankel, J. and S.-J. Wei (1994), "Yen Bloc or Dollar Bloc Exchange Rate Policies of the East Asian Economies," in T. Ito and A. O. Krueger (eds.) Macroeconomic Linkages: Savings, Exchange Rates and Capital Flows, Chicago: University of Chicago Press, pp. 295-333.

Fratzscher, M. and A. Mehl (2011), "China's Dominance Hypothesis and the Emergence of a Tri-polar Global Currency System," ECB Working Paper No. 1392, European Central Bank, Frankfurt.

Germain, R. and H. Schwartz (2014), "The Political Economy of Failure: The Euro as an International Currency," Review of International Political Economy, Vol. 21(5), pp. 1095-1122.

Goldberg, L. S. and C. Tille (2005), "Vehicle Currency Use in International Trade," NBER Working Paper No. 11127, National Bureau of Economic Research, Cambridge, MA. 
Helleiner, E. (2008), "Political Determinants of International Currencies: What Future for the US Dollar?" Review of International Political Economy, Vol. 15(3), pp. 354-378.

Helleiner, E. and J. Kirshner (2009), "The Future of the Dollar: Whither the Key Currency?" in E. Helleiner and J. Kirshner (eds.) The Future of the Dollar, Ithaca, NY: Cornell University Press, pp. 1-23.

(eds.) (2014), The Great Wall of Money: Power and Politics in China's International Monetary Relations, Ithaca and London: Cornell University Press.

Helleiner, E. and A. Malkin (2012), "Sectoral Interests and Global Money: Renminbi, Dollars and the Domestic Foundations of International Currency Policy," Open Economies Review, Vol. 23(1), pp. 33-55.

IMF (International Monetary Fund) (2014a), "Offshore Financial Centers (OFCs): IMF Staff Assessments," https://www.imf.org/external/NP/ofca/OFCA.aspx, accessed January 18, 2016.

(2014b), "Annual Report on Exchange Arrangements and Exchange Restrictions 2014,” International Monetary Fund, Washington, DC.

(2015), "Review of the Method of Valuation of the SDR," IMF Policy Paper, International Monetary Fund, Washington, DC.

Ito, T. (2010), "China as Number One: How about the Renminbi?" Asian Economic Policy Review, Vol. 5(2), pp. 249-276.

Johnson, J. (2008), "Forbidden Fruit: Russia's Uneasy Relationship with the U.S. Dollar," Review of International Political Economy, Vol. 15(3), pp. 379-398.

Katada, S. N. (2008), "From a Supporter to a Challenger? Japan's Currency Leadership in Dollar-dominated East Asia," Review of International Political Economy, Vol. 15(3), pp. 399-417.

Kawai, M. and V. Pontines (2014), "Is There Really a Renminbi Bloc in Asia?" ADBI Working Paper No. 467, Asian Development Bank Institute, Tokyo. 
Kindleberger, C. P. (1967), "The Politics of International Money and World Language," Essays in International Finance No. 61, Princeton University, Princeton, NJ.

Kirshner, J. (2008), "Dollar Primacy and American Power: What's at Stake?" Review of International Political Economy, Vol. 15(3), pp. 418-438. (2009), "After the (Relative) Fall: Dollar Diminution and the Consequences for American Power," in E. Helleiner and J. Kirshner (eds.) The Future of the Dollar, Ithaca, NY: Cornell University Press, pp. 191-215.

Krugman, P. (1984), "The International Role of the Dollar: Theory and Prospect," in J. Bilson and R. Marston (eds.) Exchange Rate Theory and Practice, Chicago, IL: University of Chicago Press, pp. 261-278.

Lee, J.-W. (2014), "Will the Renminbi Emerge as an International Reserve Currency?" The World Economy, Vol. 37(1), pp. 42-62.

Liao, S. and D. E. McDowell (2015), "Redback Rising: China's Bilateral Swap Agreements and Renminbi Internationalization," International Studies Quarterly, Vol. 59(3), pp. 401-422.

(2016), "No Reservations: International Order and Demand for the Renminni as a Reserve Currency," International Studies Quarterly, DOI: http://dx.doi.org/10.1093/isq/sqv020.

Lim, E.-G. (2006), "The Euro's Challenge to the Dollar: Different Views from Economists and Evidence from COFER (Currency Composition of Foreign Exchange Reserves) and Other Data," IMF Working Paper WP/06/153, International Monetary Fund, Washington, DC.

Long Finance (2015), "The Global Financial Centres Index 18," http://www.longfinance.net/publications.html?id=953, accessed November 3, 2015.

Ly, M. (2012), "Special Drawing Rights, the Dollar, and the Institutionalist Approach to Reserve Currency Status," Review of International Political Economy, Vol. 19(2), pp. 341-362.

McKinnon, R. (2009), "U.S. Current Account Deficits and the Dollar Standard's Sustainability: A Monetary Approach," in E. Helleiner and J. Kirshner (eds.) The Future of the Dollar, Ithaca, NY: Cornell University Press, pp. 45-68. 
McNamara, K. R. (2008), "A Rivalry in the Making? The Euro and International Monetary Power," Review of International Political Economy, Vol. 15(3), pp. 439-59.

Momani, B. (2008), "Gulf Cooperation Council Oil Exporters and the Future of the Dollar," New Political Economy, Vol. 13(3), pp. 293-314.

Norrlof, C. (2014), "Dollar Hegemony: A Power Analysis," Review of International Political Economy, Vol. 21(5), pp. 1042-1070.

Otero-Iglesias, M. and F. Steinberg (2012), "Is the Dollar Becoming a Negotiated Currency? Evidence from Emerging Markets," New Political Economy, Vol. 18(3), pp. 309-336.

(2013), "Reframing the Euro vs. Dollar Debate through the Perceptions of Financial Elites in Key Dollar-Holding Countries," Review of International Political Economy, Vol. 20(1), pp. 180-214.

Pampel, F. C. (2000), Logistic Regression: A Primer, Sage University Paper Series on Quantitative Applications in the Social Sciences Series No. 132, London: Sage Publications.

Pittaluga, G. B. and E. Seghezza (2012), "Euro vs Dollar: An Improbable Threat," Open Economies Review, Vol. 23(1), pp. 89-108.

Posen, A. S. (2008), "Why the Euro Will Not Rival the Dollar," International Finance, Vol. 11(1), pp. 75-100.

Rose, A. K. (2014), "Surprising Similarities: Recent Monetary Regimes of Small Economies," Journal of International Money and Finance, Vol. 49, pp. 5-27.

Salant, W. A. (1964), "The Reserve Currency Role of the Dollar: Blessing or Burden to the United States?" Review of Economics and Statistics, Vol. 46(2), pp. 165-172.

Stokes, D. (2014), "Achilles' Deal: Dollar Decline and U.S. Grand Strategy after the Crisis," Review of International Political Economy, Vol. 21(5), pp. 1071-1094.

Strange, S. (1971), Sterling and British Policy: A Political Study of an International Currency in Decline, London: Oxford University Press. 
Subramanian, A. (2011), Eclipse: Living in the Shadow of China's Economic Dominance, Washington, DC: Peterson Institute for International Economics.

Subramanian, A. and M. Kessler (2012), "The Renminbi Bloc Is Here: Asia Down, Rest of the World to Go?" Working Paper WP 12-19, Peterson Institute for International Economics, Washington, DC.

Swoboda, A. K. (1968), "The Euro-Dollar Market: An Interpretation," Essays in International Finance No. 64, Princeton University, Princeton, NJ.

Tavlas, G. S. (1991), "On the International Use of Currencies: The Case of the Deutsche Mark," Essays in International Finance No. 181, Princeton University, Princeton, NJ.

Tavlas, G. S. and Y. Ozeki (1992), "The Internationalization of Currencies: An Appraisal of the Japanese Yen,” IMF Occasional Paper No. 90, International Monetary Fund, Washington, DC.

Triffin, R. (1968), Our International Monetary System: Yesterday, Today, and Tomorrow, New York: Random House.

Walter, A. (2006), "Domestic Sources of International Monetary Leadership," in D. M. Andrews (ed.) International Monetary Power, Ithaca, NY: Cornell University Press, pp. 51-71.

World Economic Forum (2012), "The Financial Development Report 2012," http://www3.weforum.org/docs/WEF_FinancialDevelopmentReport_2012.pdf, accessed November 15, 2015.

Yao, K. and D. Lawder (2016), "China Gives U.S. Investment Quota for First Time to Deepen Financial Ties," Reuters, June 7, available at http://www.reuters.com/article/us-china-usa-rqfii-idUSKCN0YT1F2.

Yu, Y. (2014), "How Far Can Renminbi Internationalization Go?" ADBI Working Paper No. 461, Asian Development Bank Institute, Tokyo. 


\section{Appendix}

Table A.1. Labels of Variables, and Data Sources

\begin{tabular}{|c|c|}
\hline Variable & Source \\
\hline RMB infrastructure & PBoC, CFETS, SAFE and various media \\
\hline RMB reserve holding & various media \\
\hline Global financial center status & Long Finance (2015) \\
\hline 'Global Financial Centres Index' & Long Finance (2015) \\
\hline ‘Financial Development Index’ & World Economic Forum (2012) \\
\hline Trade reliance on China & DOTS and WEO \\
\hline Investment reliance on China & UNCTAD and WEO \\
\hline Trade reliance on US & DOTS and WEO \\
\hline Investment reliance on US & UNCTAD and WEO \\
\hline PTA with China & MoC and ADB \\
\hline BIT with China & UNCTAD \\
\hline PTA with US & USTR \\
\hline BIT with US & UNCTAD \\
\hline Security ties with China & SCO website \\
\hline Ideological distance from China & Baily, Strezhnev and Voeten (2015) \\
\hline Territorial dispute with China & $\mathrm{ClA}$ \\
\hline Security ties with US & Wikipedia \\
\hline Population of ethnic Chinese & 2013 Economic Year Book on Overseas Chinese \\
\hline Type of exchange rate regime & $\operatorname{IMF}(2014 b)$ \\
\hline Financial openness & Chinn-Ito Index \\
\hline Eurozone membership & European Commission \\
\hline
\end{tabular}


Table A.2. Descriptive Statistics

\begin{tabular}{|c|c|c|c|c|c|}
\hline Variable & Obs & Mean & Std. dev & Min & $\operatorname{Max}$ \\
\hline $\begin{array}{l}\text { RMB infrastructure (three-point scale } \\
\text { categorical variable) }\end{array}$ & 249 & 0.365 & 0.628 & 0 & 2 \\
\hline Simple count of RMB infrastructures & 249 & 0.618 & 1.213 & 0 & 5 \\
\hline RMB reserve holding & 249 & 0.153 & 0.360 & 0 & 1 \\
\hline Global financial center status & 249 & 0.843 & 1.719 & 0 & 6 \\
\hline 'Global Financial Centres Index' score & 62 & 652.871 & 52.256 & 537 & 796 \\
\hline 'Financial Development Index' score & 62 & 3.716 & 0.805 & 2.37 & 5.31 \\
\hline Trade reliance on China & 187 & 10.661 & 17.029 & 0 & 149.075 \\
\hline Investment reliance on China & 187 & 18.022 & 185.203 & -0.026 & 2505.424 \\
\hline Trade reliance on US & 187 & 6.550 & 9.021 & 0 & 52.390 \\
\hline Investment reliance on US & 187 & 21.461 & 157.440 & -15.517 & 2048.37 \\
\hline PTA with China & 249 & 0.097 & 0.296 & 0 & 1 \\
\hline BIT with China & 249 & 0.438 & 0.497 & 0 & 1 \\
\hline PTA with US & 249 & 0.080 & 0.272 & 0 & 1 \\
\hline BIT with US & 249 & 0.161 & 0.368 & 0 & 1 \\
\hline Security ties with China & 249 & 0.024 & 0.154 & 0 & 1 \\
\hline Ideological distance from China & 190 & 0.723 & 0.720 & 0.001 & 3.184 \\
\hline Territorial dispute with China & 249 & 0.044 & 0.206 & 0 & 1 \\
\hline Security ties with US & 249 & 0.120 & 0.326 & 0 & 1 \\
\hline Population of ethnic Chinese & 247 & 4.081 & 5.062 & 0 & 15.925 \\
\hline Type of exchange rate regime & 189 & 2.995 & 1.244 & 1 & 5 \\
\hline Financial openness & 174 & 0.531 & 0.380 & 0 & 1 \\
\hline Eurozone membership & 249 & 0.076 & 0.266 & 0 & 1 \\
\hline
\end{tabular}




\section{$<$ Abstract in Korean $>$}

\section{통화국제화 과정에서의 선도적 사용자에 대한 분석 : 수요자 측면에서의 위안화 국제화 사례연구}

\section{최형규*, 김근영**, 이동현***}

새로운 국제통화의 부상은 동 통화의 국제화 초기 단계에서 이를 적극 적으로 사용하는 '선도적 사용자(first users)'에 의해 주도된다. 따라서 새로 운 국제통화의 선도적 사용자가 누구인가 하는 주제는 새로운 국제통화질 서 형성과정을 이해하는 데 있어 매우 중요하다. 하지만 대다수 기존 연구 들은 국제통화 발행국(international currency issuers)의 국내 경제 및 정치적 여건을 분석하는 '공급자 측면(supply side)' 접근법을 채택하고 있으며, 새로 운 국제통화의 선도적 사용자의 특성에 대한 체계적인 연구는 극히 미흡한 실 정이다.

본 연구는 중국 위안화 국제화 사례를 중심으로, 국제통화 사용자 (international currency users)를 분석하는 '수요자 측면(demand side)' 접근법을 통해 본 주제를 분석하였다. 분석방법으로는 종속변수와 설명변수간 비선형 관계를 반영할 수 있는 순위형 로짓 회귀분석(generalized ordered logistic regression)을 이용하였다.

본 연구의 주요 분석결과는 다음과 같다. 먼저 주요 국제금융중심지가 위치한 국가의 경우 자국에서의 위안화 사용을 증진하고자 하는 경향을 보였다. 이는 글로벌 금융경쟁력을 유지하려는 금융기관의 노력과 이를 뒷받침하고자 하는 국가간 경쟁이 새로운 국제통화질서의 형성에 주요한 역할을 하였음을 시사한다. 다음으로 중국과 무역협정 및 투자협정 등과 같 은 제도적 경제협력을 구축한 국가일수록 자국에서의 위안화 사용을 늘리는 데 보다 적극적인 것으로 나타났다. 반면 무역 혹은 투자 규모와 같은 단순 한 대중 경제교류 정도는 위안화 국제화 초기단계에서 각국 정부의 위안 화 사용과 관련한 정책에 유의미한 영향을 미치지 않았다.

핵심 주제어: 통화국제화, 국제통화, 인민폐 국제화, 위안화 국제화, 기축통화 JEL Classification: F33, F50

\footnotetext{
* 일본 정책연구대학원대학 부교수(E-mail: hyoung-kyu@grips.ac.jp)

** 한국은행 조사국 국제종합팀 팀장(전화: 02-759-5280, E-mail: kgy3104@bok.or.kr)

*** 한국은행 경제연구원 북한경제연구실 연구위원(전화: 02-759-5441, E-mail: dukelee@bok.or.kr)
}

이 연구내용은 집필자들의 개인의견이며 한국은행의 공식견해와는 무관합니다. 따라서 본 논문의 내용을 보도하거나 인용할 경우에는 집팔자명을 반드시 명시하여 주시기 바랍니다. 


\section{$\mathrm{BOK}$ 경제연구 발간목록}

한국은행 경제연구원에서는 Working Paper인 ${ }^{\mathrm{B} B O K}$ 경제연구』를 수시로 발간하고 있습니다. 『BOK 경제연구』는 주요 경제 현상 및 정책 효과에 대한 직관적 설명 뿐 아니라 깊이 있는 이론 또는 실증 분석을 제공함으로써 엄밀한 논증에 초점을 두는 학술논문 형태의 연구이며 한국은행 직원 및 한국은행 연구용역사업의 연구 결과물이 수록되고 있습니다.

${ }^{\circledR} \mathrm{BOK}$ 경제연구』는 한국은행 경제연구원 홈페이지(http://imer.bok.or.kr)에서 다운로드하여 보실 수 있습니다.

제2014-1 Network Indicators for Monitoring Intraday Liquidity in BOK-Wire+

2 중소기업에 대한 신용정책 효과

3 경제충격 효과의 산업간 공행성 분석

4 서비스업 발전을 통한 내외수 균형성장: 기대효과 및 리스크

5 Cross-country-heterogeneous and Time-varying Effects of Unconventional Monetary Policies in AEs on Portfolio Inflows to EMEs

6 인터넷뱅킹, 결제성예금 및 은행 수익성과의 관계 분석

7 Dissecting Foreign Bank Lending Behavior During the 2008-2009 Crisis

8 The Impact of Foreign Banks on Monetary Policy Transmission during the Global Financial Crisis of 2008-2009: Evidence from Korea

9 Welfare Cost of Business Cycles in Economies with Individual Consumption Risk

10 Investor Trading Behavior Around the Time of Geopolitical Risk Events: Evidence from South Korea

11 Imported-Inputs Channel of Exchange Rate Pass-Through: Evidence from Korean Firm-Level Pricing Survey
Seungjin Baek

Kimmo Soram ki . Jaeho Yoon

정호성·임호성

황선웅·민성환 ·

신동현 · 김기호

김승원 · 황광명

Kyoungsoo Yoon •

Christophe Hurlin

이동규·전봉걸

Moon Jung Choi •

Eva Gutierrez •

Maria Soledad Martinez Peria

Bang Nam Jeon •

Hosung Lim. Ji Wu

Martin Ellison •

Thomas J. Sargent

Young Han Kim •

Hosung Jung

Jae Bin Ahn -

Chang-Gui Park 


\begin{tabular}{|c|c|c|}
\hline 제2014-12 & 비대칭 금리기간구조에 대한 실증분석 & 김기호 \\
\hline 13 & $\begin{array}{l}\text { The Effects of Globalization } \\
\text { on Macroeconomic Dynamics } \\
\text { in a Trade-Dependent Economy: } \\
\text { the Case of Korea }\end{array}$ & Fabio Milani $\cdot$ Sung Ho Park \\
\hline 14 & $\begin{array}{l}\text { 국제 포트폴리오투자 행태 분석: 채권-주식 } \\
\text { 투자자금간 상호관계를 중심으로 }\end{array}$ & 이주용·김근영 \\
\hline 15 & $\begin{array}{l}\text { 북한 경제의 추격 성장 가능성과 } \\
\text { 정책 선택 시나리오 }\end{array}$ & 이근 · 최지영 \\
\hline 16 & $\begin{array}{l}\text { Mapping Korea's International Linkages } \\
\text { using Generalised Connectedness Measures }\end{array}$ & Hail Park $\cdot$ Yongcheol Shin \\
\hline 17 & $\begin{array}{l}\text { 국제자본이동 하에서 환율신축성과 } \\
\text { 경상수지 조정: 국가패널 분석 }\end{array}$ & 김근영 \\
\hline 18 & $\begin{array}{l}\text { 외국인 투자자가 외환시장과 주식시장 간 } \\
\text { 유동성 동행화에 미치는 영향 }\end{array}$ & 김준한 $\cdot$ 이지은 \\
\hline 19 & $\begin{array}{l}\text { Forecasting the Term Structure } \\
\text { of Government Bond Yields } \\
\text { Using Credit Spreads and Structural Breaks }\end{array}$ & $\begin{array}{l}\text { Azamat Abdymomunov } \\
\text { Kyu Ho Kang } \\
\text { Ki Jeong Kim }\end{array}$ \\
\hline 20 & $\begin{array}{l}\text { Impact of Demographic Change } \\
\text { upon the Sustainability of Fiscal Policy }\end{array}$ & $\begin{array}{l}\text { Younggak } \mathrm{Kim} \cdot \\
\text { Myoung Chul Kim } \\
\text { Seongyong Im }\end{array}$ \\
\hline 21 & $\begin{array}{l}\text { The Impact of Population Aging } \\
\text { on the Countercyclical Fiscal Stance in Korea, } \\
\text { with a Focus on the Automatic Stabilizer }\end{array}$ & $\begin{array}{l}\text { Tae-Jeong Kim } \cdot \\
\text { Mihye Lee } \cdot \text { Robert Dekle }\end{array}$ \\
\hline 22 & $\begin{array}{l}\text { 미 연준과 유럽중앙은행의 비전통적 통화정책 } \\
\text { 수행원칙에 관한 고찰 }\end{array}$ & 김병기·김진일 \\
\hline 23 & $\begin{array}{l}\text { 우리나라 일반인의 인플레이션 기대 형성 } \\
\text { 행태 분석 }\end{array}$ & 이한규·최진호 \\
\hline
\end{tabular}


제2014-24 Nonlinearity in Nexus between

Working Hours and Productivity

25 Strategies for Reforming Korea's Labor Market to Foster Growth

26 글로벌 금융위기 이후 성장잠재력 확충: 2014 한국은행 국제컨퍼런스 결과보고서

27 인구구조 변화가 경제성장률에 미치는 영향: 자본이동의 역할에 대한 논의를 중심으로

28 Safe Assets

29 확장된 실업지표를 이용한 우리나라 노동시장에서의 이력현상 분석

Entropy of Global Financial Linkages

31 International Currencies Past, Present and Future: Two Views from Economic History

32 금융체제 이행 및 통합 사례:

남북한 금융통합에 대한 시사점

Measuring Price-Level Uncertainty and Instability in the U.S., 1850-2012

고용보호제도가 노동시장 이원화

및 노동생산성에 미치는 영향

35 해외충격시 외화예금의 역할 : 주요 신흥국 신용스프레드에 미치는 영향을 중심으로 Emerging Market Economies, and Their Policy Responses
Dongyeol Lee

Hyunjoon Lim

Mai Dao · Davide Furceri •

Jisoo Hwang

Meeyeon Kim •

Tae-Jeong Kim

한국은행 경제연구원

손종칠

Robert J. Barro

김현학 · 황광명

Daeyup Lee

Barry Eichengreen

김병연

Timothy Cogley •

Thomas J. Sargent

김승원

정호성 - 우준명

김인수 · 이명수

황광명 - 김경민 -

노충식·김미진

Woon Gyu Choi •

Taesu Kang •

Geun-Young Kim •

Byongju Lee 
제2015-1 글로벌 금융위기 이후 주요국

통화정책 운영체계의 변화

2 미국 장기시장금리 변동이 우리나라 금리기간구조에 미치는 영향 분석 및 정책적 시사점

3 직간접 무역연계성을 통한 해외충격의 우리나라 수출입 파급효과 분석

4 통화정책 효과의 지역적 차이

5 수입중간재의 비용효과를 고려한 환율변동과 수출가격 간의 관계

6 중앙은행의 정책금리 발표가 주식시장 유동성에 미치는 영향

7 은행 건전성지표의 변동요인과 거시건전성 규제의 영향

8 Price Discovery and Foreign Participation in The Republic of Korea's Government Bond Futures and Cash Markets

9 규제가 노동생산성에 미치는 영향:

한국의 산업패널 자료를 이용한 실증분석

10 인구 고령화와 정년연장 연구

(세대 간 중첩모형(OLG)을 이용한 정량 분석)

11 예측조합 및 밀도함수에 의한 소비자물가 상승률 전망

12 인플레이션 동학과 통화정책

13 Failure Risk and the Cross-Section of Hedge Fund Returns

14 Global Liquidity and Commodity Prices

15 Foreign Ownership, Legal System and Stock Market Liquidity
김병기·김인수

강규호·오형석

최문정·김근영

김기호

김경민

이지은

강종구

Jaehun Choi - Hosung Lim •

Rogelio Jr. Mercado •

Cyn-Young Park

이동렬· 최종일·이종한

홍재화 - 강태수

김현학

우준명

Jung-Min Kim

Hyunju Kang •

Bok-Keun $\mathrm{Yu}$.

Jongmin $\mathrm{Yu}$

Jieun Lee $\cdot$ Kee H. Chung 
제2015-16 바젤 II 은행 경기대응완충자본 규제의 기준지표에 대한 연구

17 우리나라 대출 수요와 공급의 변동요인 분석

18 북한 인구구조의 변화 추이와 시사점

19 Entry of Non-financial Firms and Competition in the Retail Payments Market

20 Monetary Policy Regime Change and Regional Inflation Dynamics: Looking through the Lens of Sector-Level Data for Korea

21 Costs of Foreign Capital Flows in Emerging Market Economies: Unexpected Economic Growth and Increased Financial Market Volatility

22 글로벌 금리 정상화와 통화정책 과제: 2015년 한국은행 국제컨퍼런스 결과보고서

23 The Effects of Global Liquidity on Global Imbalances

24 실물경기를 고려한 내재 유동성 측정

25 Deflation and Monetary Policy

26 Macroeconomic Shocks and Dynamics of Labor Markets in Korea

27 Reference Rates and Monetary Policy Effectiveness in Korea

28 Energy Efficiency and Firm Growth

29 An Analysis of Trade Patterns in East Asia and the Effects of the Real Exchange Rate Movements

30 Forecasting Financial Stress Indices in Korea: A Factor Model Approach
서현덕·이정연

강종구 · 임호성

최지영

Jooyong Jun

Chi-Young Choi •

Joo Yong Lee

Roisin O'Sullivan

Kyoungsoo Yoon • Jayoung Kim

한국은행 경제연구원

Marie-Louise DJIGBENOU-KRE •

Hail Park

우준명·이지은

Barry Eichengreen

Tae Bong Kim •

Hangyu Lee

Heung Soon Jung •

Dong Jin Lee .

Tae Hyo Gwon .

Se Jin Yun

Bongseok Choi •

Wooyoung Park.

Bok-Keun Yu

Moon Jung Choi •

Geun-Young Kim • Joo Yong Lee

Hyeongwoo Kim • Hyun Hak Kim. Wen Shi 


\begin{tabular}{|c|c|c|}
\hline 제2016 -1 & $\begin{array}{l}\text { The Spillover Effects of U.S. Monetary } \\
\text { Policy on Emerging Market Economies: } \\
\text { Breaks, Asymmetries and } \\
\text { Fundamentals }\end{array}$ & $\begin{array}{l}\text { Geun-Young Kim } \cdot \\
\text { Hail Park· } \\
\text { Peter Tillmann }\end{array}$ \\
\hline 2 & $\begin{array}{l}\text { Pass-Through of Imported Input Prices } \\
\text { to Domestic Producer Prices: Evidence } \\
\text { from Sector-Level Data }\end{array}$ & $\begin{array}{l}\text { JaeBin Ahn } \\
\text { Chang-Gui Park } \\
\text { Chanho Park }\end{array}$ \\
\hline 3 & $\begin{array}{l}\text { Spillovers from U.S. Unconventional } \\
\text { Monetary Policy and Its Normalization } \\
\text { to Emerging Markets: A Capital Flow } \\
\text { Perspective }\end{array}$ & $\begin{array}{l}\text { Sangwon Suh } \\
\text { Byung-Soo Koo }\end{array}$ \\
\hline 4 & $\begin{array}{l}\text { Stock Returns and Mutual Fund Flows } \\
\text { in the Korean Financial Market: } \\
\text { A System Approach }\end{array}$ & $\begin{array}{l}\text { Jaebeom Kim } \\
\text { Jung-Min Kim }\end{array}$ \\
\hline 5 & $\begin{array}{l}\text { 정책금리 변동이 성별·세대별 고용률에 } \\
\text { 미치는 영향 }\end{array}$ & 정성엽 \\
\hline 6 & $\begin{array}{l}\text { From Firm-level Imports to Aggregate } \\
\text { Productivity: Evidence from Korean } \\
\text { Manufacturing Firms Data }\end{array}$ & $\begin{array}{l}\text { JaeBin Ahn } \\
\text { Moon Jung Choi }\end{array}$ \\
\hline 7 & $\begin{array}{l}\text { 자유무역협정(FTA)이 한국 기업의 } \\
\text { 기업내 무역에 미친 효과 }\end{array}$ & 전봉걸·김은숙 $\cdot$ 이주용 \\
\hline 8 & $\begin{array}{l}\text { The Relation Between Monetary and } \\
\text { Macroprudential Policy }\end{array}$ & Jong Ku Kang \\
\hline 9 & $\begin{array}{l}\text { 조세피난처 투자자가 투자 기업 및 주식 } \\
\text { 시장에 미치는 영향 }\end{array}$ & 정호성·김순호 \\
\hline 10 & $\begin{array}{l}\text { 주택실거래 자료를 이용한 주택부문 거시 } \\
\text { 건전성 정책 효과 분석 }\end{array}$ & 정호성·이지은 \\
\hline 11 & $\begin{array}{l}\text { Does Intra-Regional Trade Matter in } \\
\text { Regional Stock Markets?: New } \\
\text { Evidence from Asia-Pacific Region }\end{array}$ & $\begin{array}{l}\text { Sei-Wan Kim } \\
\text { Moon Jung Choi }\end{array}$ \\
\hline 12 & $\begin{array}{l}\text { Liability, Information, and Anti-fraud } \\
\text { Investment in a Layered Retail } \\
\text { Payment Structure }\end{array}$ & $\begin{array}{l}\text { Kyoung-Soo Yoon } \\
\text { Jooyong Jun }\end{array}$ \\
\hline 13 & $\begin{array}{l}\text { Testing the Labor Market Dualism in } \\
\text { Korea }\end{array}$ & $\begin{array}{l}\text { Sungyup Chung. } \\
\text { Sunyoung Jung }\end{array}$ \\
\hline 14 & $\begin{array}{l}\text { 북한 이중경제 사회계정행렬 추정을 통한 } \\
\text { 비공식부문 분석 }\end{array}$ & 최지영 \\
\hline
\end{tabular}



$\begin{array}{ll}\text { 제2016-15 } & \begin{array}{l}\text { Divergent EME Responses to Global } \\ \text { and Domestic Monetary Policy Shocks }\end{array}\end{array}$

16 Loan Rate Differences across Financial Sectors: A Mechanism Design Approach

17 근로자의 고용형태가 임금 및 소득 분포 최충-정성엽 에 미치는 영향

18 Endogeneity of Inflation Target

19 Who Are the First Users of a Newly-Emerging International Currency? A Demand-Side Study of Chinese Renminbi Internationalization
Woon Gyu Choi ·

Byongju Lee .

Taesu Kang •

Geun-Young Kim

Byoung-Ki Kim • Jun Gyu Min

Soyoung Kim • Geunhyung Yim

Hyoung-kyu Chey • Geun-Young Kim •

Dong Hyun Lee 